\title{
A RESPONSABILIDADE (DIACRÔNICA) PELA TUTELA DOS BENS AMBIENTAIS: IMPORTANTES NOTAS PARA O DIREITO PENAL AMBIENTAL
}

\author{
Matheus Almeida Caetano ${ }^{1}$
}

\section{Resumo}

Tenta-se confrontar aqui o problema da (in)compatibilidade entre as racionalidades jurídicas ambiental e penal no tocante a proteção dos bens ambientais em favor das gerações futuras, especialmente pelas dificuldades de verificação da causalidade em danos ambientais em contextos de atos individuais com consequências acumulativas. O objetivo geral deste artigo é esboçar os limites do Direito Penal na tutela dos bens ambientais diante da superestimada proteção das gerações futuras. Como justificativa, esta revisão bibliográfica funda-se na dispensa de ofensa a bens jurídicos, bem como na verdadeira diluição dos pressupostos de responsabilidade jurídico-penal (principalmente os de natureza individual e subjetiva da imputação, por exemplo, a imprescindibilidade da causalidade e da culpabilidade) presentes nomeadamente no direito penal de precaução e nos crimes de acumulação. O predomínio do método dedutivo caracteriza esta abordagem metodológica, e, a documentação indireta, marcada pela pesquisa bibliográfica, consiste na técnica de pesquisa empregada aqui. Como resultado, conclui-se que o Direito Penal Ambiental só tem legitimidade para tutelar alguns dos bens jurídicos ambientais, dentro de um determinado espaço temporal (no interesse das gerações atuais, as únicas determináveis), das ofensas mais graves (segundo os princípios da ofensividade, ultima ratio, fragmentaridade e subsidiariedade).

Palavras-chave: Responsabilidades sincrônica e diacrônica. Obrigações simétricas e assimétricas. Proteção jurídica das gerações futuras.

\section{INTRODUÇÃO}

Apesar de não ignorarmos, desde tempos remotos, as várias manifestações do homem para com as gerações vindouras (ou futuras), esta "preocupação" ganhou contornos marcantes a partir do século passado em

\footnotetext{
${ }^{1}$ Doutorando em "Ciências Jurídico-Criminais" pela Faculdade de Direito da Universidade de Coimbra (FDUC). Pesquisadorvisitante junto ao Strafrechtliches Institut der Rheinische Friedrich-Wilhelms Universität Bonn. Membro dos Grupos de Pesquisa "Direito Ambiental e Ecologia Política na Sociedade de Risco" (UFSC), "'o Direito e o Tempo"(FDUC-PT), "Direito Penal Contemporâneo e Teoria do Crime", Fundamento, função e estruturação do direito penal normativo na sociedade contemporânea" (PUC-RS). Bolsista do Programa de Doutoramento Pleno no Exterior (CAPES). E-mail: matheusacaetano@gmail.com

2 Trata-se de referência à categoria da "preocupação" enquanto elemento do "modelo íntimo" proposto por Ortega y Gasset (2004, p. 190 e s.) ao tratar da "realidade radical”: a nossa vida e o constante exercício de planejar e executar o que vamos ser. Partindo da ideia central de Heidegger em "Sein und Zeit", scilicet, a vida como cuidado (die Sorge), o filósofo espanhol propõe que a "vida é preocupação", o que se reflete no cotidiano "ocupar-se antecipadamente, é preocupar-se".
} 
razão de uma série de fatos históricos ${ }^{3}$ que representou o quase absoluto poder-dominação do homem sobre o homem e sobre a natureza, acionando o alarme de uma provável tragédia da humanidade. O elemento comum a todos esses fatos e que permitiu vislumbrar a relevância da responsabilidade pelas gerações futuras, de uma forma dolorosamente concreta, foram os efeitos (ou consequências) intergeracionais ${ }^{4}$. Vejamos. Kim Phuc ${ }^{5}$ levará por toda a vida as cicatrizes deixadas pelo flamejante napalm (outros vietnamitas e seus descendentes herdaram variadas formas de cânceres e problemas congênitos e neurológicos), os hibakusha ${ }^{6}$ trazem (e levarão) marcas físicas e psíquicas das bombas atômicas, inclusive as gerações posteriores à catástrofe têm nascido com anomalias geradas pela radiação nuclear, bem como o mercúrio e os elementos radioativos manifestam-se ainda hoje nos ambientes e nas novas gerações de Minamata e de Chernobyl, vítimas das flechas química e radioativa que atravessam gerações. Essas foram algumas das manifestações dos efeitos intergeracionais, os quais, infelizmente, repetiram-se em 2011 e tem ressonância (e ainda o terão amanhã...) em Fukushima...

A partir disso, as intervenções genéticas nas bases da vida, os esgotamentos de estoques minerais, as extinções de espécies, o lixo atômico, a destruição da camada de ozônio, o efeito estufa, o aquecimento global, as poluições irreversíveis ou de longa duração da atmosfera, da água e do solo, passaram a ser compreendidos como "ameaças ao futuro" (STRATENWERTH, 1993, p. 680). Os fatos históricos supramencionados e as

\footnotetext{
${ }^{3}$ Cronologicamente poderíamos iniciar esta série de fatos históricos pelo contexto da Segunda Guerra Mundial, com o ambivalente sucesso científico/fracasso ético das bombas atômicas lançadas pelos Estados Unidos da América (EUA), em seis de agosto de 1945, sobre as cidades japonesas de Hiroshima e de Nagasaki. Posteriormente, na Guerra do Vietnã dizimaram-se milhares de vietnamitas não surpreendentemente com o auxílio da ciência, e aqui, chama-se a atenção para a arma química utilizada pelos estadunidenses como tática de guerra: o napalm (o agente laranja), que, pulverizado por aviões para desfolhar a vegetação das florestas com o fim de facilitar a identificação dos inimigos, provocava a combustão imediata de qualquer organismo vivo com o qual entrava em contato. Por fim, embora não tenha ocorrido um conflito real, a Guerra Fria representou um dos capítulos mais tensos da história da humanidade, diante da iminência de um conflito nuclear entre os dois polos hegemônicos do planeta (o socialista capitaneado pela União das Repúblicas Socialistas Soviéticas e o capitalista pelos EUA) à época. Mencionamos também os seguintes acidentes ambientais: (i) o derramamento industrial de mercúrio na baía de Minamata, Japão (1956); (ii) o acidente nuclear de Three Mile Island, EUA (1979); (iii) os desastres químicos de Seveso, Itália (1976); e (iv) de Bhopal, Índia (1984); (v) os acidentes nucleares de Chernobyl, Ucrânia (1986), e (vi) com o Césio 137, Goiânia-Brasil (1987).

${ }^{4}$ Intergeracionais porque não afetam apenas as gerações que vivenciaram os eventos no mesmo tempo e espaço, cfr. o conceito de "equidade intergeracional" na nota 20. Apenas a título ilustrativo, seguem algumas expressões que sufragam esse diagnóstico, cfr.: Weiss (1989) emprega em sua teoria da equidade intergeracional os seguintes termos: "long-range problems", "long-term perspective" (p. 119), "long-term effects on health or the natural environment" (p. 121) e "long-term environmental damage" (p. 206). Visser't Hooft (1991) fala em "le risque d'effets pervers frappant non seulement sa postérité directe mais également sa descendance plus lointaine" (p. 31), "certaines conséquences lointaines" (p. 37). Por sua vez, Ricoeur (1991) refere-se aos "les effets dangereux sont de dimension cosmique” (p. 271), "les effets s'étendent sur un nombre incalculable de générations” (p. 273). Ost (1995b) cita as "conséquences à long terme" (p. 296), "dommages irréversibles" (p. 289).

${ }^{5}$ Kim Phuc Phan Thi é um símbolo vivo do movimento antiguerra e vive atualmente no Canadá como Embaixadora da Boa Vontade da Organização das Nações Unidas para a Educação, a Ciência e a Cultura (UNESCO). Ela tornou-se mundialmente conhecida pelas lentes do fotógrafo (também) vietnamita Nick Ut, quando fotografada, em 1973, ainda menina (à época com nove anos de idade) correndo nua e aos prantos com as costas queimadas após o vilarejo onde morava (Trang Bang) ser atacado com napalm durante a Guerra do Vietnã.

${ }^{6}$ Trata-se da expressão japonesa que significa "sobreviventes da bomba atômica". Sendo o único país até os dias atuais que já sofreu diretamente um ataque atômico, o Japão iniciou uma campanha mundial de conscientização sobre as nefastas consequências do
} 
problemáticas suscitadas aqui comungam de um centro gravitacional comum - simbolizado aqui no "carro de Jagrená”7 de Giddens (1991, p. 140), ou ainda, no topos da sociedade (global) de risco(s) de Beck (1998 e 2006) - : a questão da responsabilidade pelas condições de existência das gerações futuras.

Por outro lado, a categoria (ético-jurídica) da responsabilidade passa a sofrer questionamentos e a sentir os inevitáveis abalos da contingência histórica, o que não escapou à percepção de Bronze, Castanheira Neves, Nietzsche, Ricouer, Saint Éxupéry e Ost. Advertindo-nos o segundo deles sobre uma verdadeira "hipertrofia da responsabilidade" (política, social, jurídica, cósmica ou qualquer outra), acompanhada de sua "dissolução" nos tempos atuais, cujo fio condutor é o abandono da dimensão ético-prática nas relações intersubjetivas. Isso significa que a responsabilidade tornou-se uma "exterioridade que oprime e se suporta mal, não tem lugar na intimidade ética que identifica e dignifica - foi SAINT ÉXUPÉRY quem disse: 'être homme c'est precisement être responsable" (CASTANHEIRA NEVES, 2010b, p. 130). ${ }^{8}$ Ou ainda, "tu te tornas eternamente responsável por aquilo que cativas. Tu és responsável pela rosa..." concluía a raposa no singelo diálogo com "o pequeno príncipe” a respeito de tantas coisas esquecidas pelo homem. A responsabilidade integra o rol (infelizmente numerus apertus, como veremos adiante) desses esquecimentos humanos, embora seja esperada por seu intermédio uma tutela das gerações futuras. Eis algumas das dificuldades que permearão o tema proposto neste trabalho.

Contextualizaremos as duas diversas modalidades de responsabilidade (a sincrônica e a diacrônica) frente aos seus respectivos titulares e concretizações jurídicas, e apontaremos algumas de suas características e coimplicações com a ética-prática, aspecto fundamental ao raciocínio a seguir proposto. Ao final, procuraremos ensaiar algumas considerações finais sobre a responsabilidade diacrônica e a problemática da proteção das (condições de existência das) gerações futuras no âmbito jurídico-penal, apontando algumas de suas manifestações e seus respectivos efeitos sob o modelo legítimo de injusto (que atenda aos pressupostos mínimos de validade jurídico-penal) através de um diagnóstico e um dilema formulados a seguir.

uso de armas nucleares, voltada para as gerações recentes e com a cooperação da Organização das Nações Unidas (ONU) e das cidades de Hiroshima e de Nagasaki, através da tradução em outras línguas dos relatos de vários hibakusha.

${ }^{7}$ Giddens (1991, p. 140) não deixa de assumir que a contemporaneidade comporta riscos que podem ser irreversíveis, principalmente para o meio ambiente, tanto que traz uma metáfora da modernidade como sendo um “carro de Jagrená", nos seguintes termos: "Sugiro substituir estas imagens pela do carro de Jagrená - uma máquina em movimento de enorme potência que, coletivamente como seres humanos, podemos guiar até certo ponto, mas que também ameaça escapar do nosso controle e poderia se espatifar [...] E nunca seremos capazes de nos sentir inteiramente seguros, porque o terreno por onde viajamos está repleto de riscos de alta-consequência”.

${ }^{8}$ Cfr. ainda o seguinte trecho "os homens não se sentem responsáveis, e sofrem sempre como um golpe aleatório o verem-se responsabilizados em vez de poderem invocar a dissolução da sua responsabilidade pela transferência para a irresponsabilização de uma socialização total” (CASTANHEIRA NEVES, 2010b, pp. 129-130, destaques do autor). Inclusive, neste espeque, Nietzsche (2008, p. 74) já advertia em 1877 que “[...] o castigado considerava o castigo também como lote do destino, e não sentia outra 'pena interior', como se fosse vítima de uma catástrofe imprevista, de um terrível fenômeno natural, de um penhasco que rola pela vertente e tudo esmaga, sem haver possibilidade de luta".

${ }^{9} \mathrm{O}$ diálogo entre o pequeno príncipe e a raposa fluidificará por todo o texto em meio às várias analogias no tocante a problemática da responsabilidade pelas condições de existência das gerações futuras, cfr.: SAINT ÉXUPÉRY, 2013, s.p.. 


\section{A PESSOA, A RESPONSABILIDADE SINCRÔNICA E OS DIREITOS DO HOMEM}

Sendo a condição de pessoa diretamente vinculada com a categoria ético-jurídica da responsabilidade, ou seja, uma pessoa apenas e justamente por sê-la, torna-se investida de responsabilidade; essa problemática acaba por ter um sentido no-e-pelo direito (CASTANHEIRA NEVES, 2010b, pp. 149-150). Primeiramente, cabe frisar que a pessoa não se confunde, rectius, não se reduz ao indivíduo (ao sujeito), enquanto esse se caracteriza por um "monologismo" solitário e autossuficiente como "(in-divisa) unidade de dimensão quantitativo-espacial", a pessoa é marcada pela "dialogicidade" comunicacional, "valor com um sentido qualitativo-intencional" (BRONZE, 2010, pp. 498 e 492, destaques do autor). ${ }^{10}$ Ainda, enquanto o "sujeito (o homem-sujeito)" constitui uma "entidade antropológica", o "homem-autor" ciente e autor de si, a pessoa ("homem-pessoa") é uma “aquisição axiológica", uma superação que não nega o "homem-sujeito", realizada por meio de atos voluntários e deliberados de vontades ressignificadas na respectiva dignidade humana (CASTANHEIRA NEVES, 2010b, pp. 149-150, destaques do autor).

O reconhecimento do outro (hetero-) e de si mesmo (auto-) como autônomo centro irradiador e portador de dignidade e de respeito é um verdadeiro pressuposto ético das relações e instituições humanas, primordialmente do direito, por isso significações como as de Hegel (1997, p. 40) - "O imperativo do direito é portanto: sê uma pessoa e respeita os outros como pessoas" - . Crava-se aqui uma recíproca implicação entre a dignidade humana e a responsabilidade, ${ }^{11}$ infelizmente esquecida pelos homens (mais uma que poderia integrar o rol daquelas citadas pela raposa ao pequeno príncipe...). Nesse sentido, os contornos da investidura de responsabilidade na pessoa manifestam-se na "correlatividade de direitos (sejam fundamentais ou outros) e de deveres", cujo reconhecimento obtido dos outros "confere-me direitos - afirmações de mim excluídas do arbítrio dos outros - ; o reconhecimento que os outros obtêm de mim impõe-me deveres - exigências que dos outros me convocam excluídas ao meu arbítrio" (CASTANHEIRA NEVES, 2010b, pp. 152-153, destaques do autor).

A simultânea e dialética condição de homem e de pessoa, de portador de direitos e de deveres, de liberdade com (e para) a comunidade, do eu-pessoal e do eu-social, condensa-se no "eticamente comunicativo ser de responsabilidade - pois a ética é, precisamente, hoje, se não erramos, um diálogo responsabilizante"

\footnotetext{
10 Ainda em termos de racionalização: “(...) a pessoalidade pressupõe o reconhecimento de uma autonomia ética comunitariamente integrada e normativo-juridicamente relevante, enquanto que a individualidade identifica uma pura unidade discreta positivo-legalisticamente conformadora" (BRONZE, 2010, p. 494).

${ }^{11}$ Conforme anota Bronze (2010, p. 503, nota 150), “(..) pois não é exato que a não assunção da responsabilidade corresponde a uma deliberada recusa prática-existencial (...) da pessoalidade comunitariamente enraizante de sujeitos éticos (...)”. No mesmo sentido, derivando do princípio da dignidade da pessoa humana a vinculação constitucional do princípio da culpa no direito penal, Faria Costa (2000, pp. 250-251) enreda um recíproco condicionamento entre a dignidade humana e a (a auto- e a hetero-) responsabilidade através da fundamentação ontoantropológica do direito: “(...) a dignidade, ao transpor-se e ao afirmar-se no seio das plúrimas relações em que se congrega e desagrega a comunidade, faz com que se assuma como responsabilidade. Uma dignidade só tem conteúdo verdadeiro se o seu reverso for trespassado pela noção de responsabilidade".
} 
(BRONZE, 2010, p. 502). ${ }^{12}$ Isto faz com que o pêndulo da responsabilidade incline-se para o da ética, ou, segundo Bronze (2010, pp. 131 e 507, nota 167), estar-se-á a falar de uma "ética da responsabilidade". Ética esta que invoca a pessoa, na qual “(...) releva os axiológico-praticamente consonantes efeitos do comportamento”, e que sem a sua "assunçãorrealização histórico-concreta" a responsabilidade não se realiza. ${ }^{13}$ Resultará, ao fim e ao cabo, da dialética entre a liberdade (homem-sujeito ou eu pessoal) e a comunidade (homem-pessoa ou eu social), ou seja, a liberdade através da comunidade que, por sua vez, é também (e concomitantemente) comunidade de liberdades, o fenômeno ético-concretizador do direito, instituição atribuidora de responsabilidades.

Mas não se trata de qualquer direito - e a historicidade não nos deixa cegar ou omitir as mazelas e atrocidades já perpetradas em seu nome ${ }^{14}$-, portanto se exige dele a "constitutiva dimensão ética", "imputadora" exclusiva de sentido de direito ao direito, bem como de sua autonomia. Serão três as "condições constitutivas e da emergência do direito" propostas por Castanheira Neves. A primeira delas, "a condição mundano-social", radica na "pluralidade humana na unicidade do mundo", scilicet, mundo único que incluí todos os demais (natural, social e cultural) e no qual partilhamos nossas relações do tipo situacional-comunicativas enquanto pessoas que se reconhecem e se respeitam como tais. ${ }^{15} \mathrm{~A}$ segunda é a "humana-existencial", na qual "a dialética de personalidade e de comunidade" ganha dimensão, procurando transcender um patrimônio civilizacional através das instituições humanas (i.e., o direito, a ordem jurídica, a política), desde que não sufoque nenhuma daquelas esferas aos custos da outra e nem fossilize as contingentes demandas ético-sociais de cada época histórica. A última condição é a ética, o que faz do direito o próprio direito, diante da qual cada pessoa reconhece a outra como sujeito ético, portador de dignidade humana e insuscetível de instrumentalização pelo poder institucional ou intersubjetivo, “(...) só assim ele poderá ser, também simultaneamente, titular de direitos (dirigidos aos outros) e de obrigações (exigidas pelos outros), em todos os níveis (...)"(CASTANHEIRA NEVES, 1999, p. 113). ${ }^{16}$

Presentes essas condições constitutivas do direito como verdadeiro direito, Castanheira Neves (2010b, pp. 155-156) aponta dois princípios axiológico-normativos fundamentais da responsabilidade jurídica, os quais

\footnotetext{
${ }^{12}$ Cfr. também: BRONZE, 2010, pp. 121-123, 126, 131, 501, 504, 507 (nota 167); BRONZE, 2012, pp. 186-191, 201-202 e 207.

${ }^{13}$ Nessa última referência, Bronze (2010, p. 507, nota 167) ao desenvolver a ideia da "ética da responsabilidade" expressamente diz: “(...) os seus dois polos se coimplicam reciprocamente (...)", ou seja, ética e responsabilidade e responsabilidade e ética.

${ }^{14}$ Embora fossem absolutamente legais as práticas dos regimes da escravidão e do extermínio de pessoas no Dritte Reich, não se pode classificá-las como legítimas ou (materialmente) válidas, portanto a crítica às teorias formais do direito (i.e., o positivismo jurídico e o funcionalismo sistêmico por excelência) decorre do padecimento do mesmo mal: faltar-lhes a dimensão ética, responsável por conferir ao direito um sentido de direito e garantir a sua autonomia como tal. Neste sentido, cfr:: CASTANHEIRA NEVES (1999, pp. 113-114; 2008, pp. 60-61 e 70; 2010a, pp. 297-300; 2010b, pp. 154-155).

${ }^{15}$ Segundo Bronze (2012, pp. 188-189) trata-se da "partilha do mundo", a qual apenas se qualificará nos dias atuais, caso nela se expressarem de forma dialeticamente correlacionais as "duas faces (...) do rosto jurídico da pessoa", scilicet, "a sua singular (e centrifuga) individualidade e a que releva a sua (centrípeta) inserção comunitária (...) como um ser de liberdade e de responsabilidade".

${ }^{16}$ Para todas as "condições constitutivas e da emergência do direito", cfr. CASTANHEIRA NEVES (1999, pp. 113-1 14; 2010b, pp. 154-155) e BRONZE (2010, p. 185, destacando ser a pessoa "o pressuposto irredutível - o dever-ser que fundamenta o dever-ser do direito".).
} 
estão coimplicados. O princípio da igualdade (A), "expressão normativa da reciprocidade das pessoas como pessoas", significa, em regra, que todos são igualmente responsáveis, não existindo alguns mais e outros menos responsáveis; e o princípio da corresponsabilidade (B) como "expressão normativa da indefectível integração comunitária das pessoas", que não se prende ao neutro e (neo) liberal neminem laedere. ${ }^{17}$

Acrescentam-se ainda três consequências normativas desses princípios. A "responsabilidade perante as condições da existência comunitária" (i) implica a corresponsabilidade dos homens-comunitariamente integrados pelas condições histórico-sociais e axiológico-culturais, porque acessíveis às condições de realização pessoal e coletiva propiciadas pela comunidade. Cumprida concretamente a igualdade material de oportunidades, todas as pessoas se tornam corresponsáveis umas pelas outras e pelas diversificadas condições proporcionadas por essa situação civilizacional, portanto para além do não causar dano a outrem (o que nos arrastaria para o offense principle) ${ }^{18}$ Insere-se aqui uma "imputação que se traduz na identificação ética do homem-pessoa com a sua ação naquele contexto comunitário em que deverá re-spondere" (CASTANHEIRA NEVES, 2010b, p. 156). A responsabilidade por reciprocidade (ii), "corresponsabilidade que é reciprocidade comutativa", transpõe o mera pacta sunt servanda, resultante de compromissos e vínculos singularmente assumidos rosto a rosto. A responsabilidade de integração comunitária (iii), cujo fundamento é o princípio da justiça, permite a responsabilização tanto pelo dano causado a outrem, ainda que no exercício de uma liberdade legítima, mas abusiva, quanto pelo prejuízo proveniente da vantagem alheia, mesmo sem fundamento superior aquele. A última resulta de um "desequilíbrio injusto que ela é chamada a denunciar e a apagar", implicando desigualdade entre as partes, seja "(...) porque se ultrapassaram os limites impostos à ação pela coexistência comunitária em recíproco reconhecimento, ou porque a realização social da pessoa não pode ser paga pelo sacrifício injustificado de outra pessoa" (CASTANHEIRANEVES, 2010b, p. 157).

Diante dessas notas, é possível caracterizar e contextualizar as duas primeiras gerações de direitos humanos, as quais têm muito a dizer sobre as particularidades da responsabilidade sincrônica. Os direitos humanos de primeira geração caracterizam-se por garantias marcadamente individuais em face (principalmente, mas não apenas) do poder do Estado - Absoluto -, portanto um non facere frente aos direitos de propriedade, liberdade, integridade física, vida, scilicet, "direitos individuais tradicionais", "obrigações puramente negativas, que implicam a abstenção de determinados comportamentos" (BOBBIO, 2004, p. 41). Essa primeira geração

\footnotetext{
${ }^{17}$ Neste aspecto, relevante lembrar o liberal harm principle no Common Law, cuja origem remonta justamente a um dos principais filósofos políticos do liberalismo (político), John Stuart-Mill (1985, pp. 141-162), em especial, em sua famosa obra publicada em 1859. Contudo, cabe (re)lembrar que, em 1766, Beccaria (2014, p. 75), por meio de sua obra "Dos delitos e das penas", já afirmava que “(...) a única e verdadeira medida do delito é o dano causado à nação”. Segundo Faria Costa (2014, p. 10), tanto esse trecho, quanto outros desse texto de Beccaria refletem "(...) a afirmação do chamado princípio da ofensividade”.

${ }^{18}$ Para mais detalhes dessa diferenciação e suas consequências, cfr.: FEINBERG, 1984, pp. 10-14.
} 
simboliza-se nos direitos de liberdade ${ }^{19}$ religiosa e de pensamento, pois atingem "a realização plena da noção de pessoa”, embora a concepção em que foram construídas (o individualismo e o cartesianismo) obstruíssem a conscientização das "exigências sociais e ecológicas", e, por isso pareciam direitos de "indivíduos isolados e autossuficientes" (BALLESTEROS, 1996, p. 24).

Já os direitos humanos de segunda geração obtêm um grande destaque no Estado Social (face às omissões do Estado Liberal) pelas exigências comunitárias por direitos à alimentação, à moradia e ao trabalho, “(...) sem os quais não são possíveis os direitos de primeira geração”, sendo, portanto, “(...) direitos do ser humano em sociedade (= solidariedade sincrônica)" (BALLESTEROS, 1996, p. 24) São exigidos atos positivos do Estado (facere) em benefício das pessoas e "(...) só podem ser realizados se for imposto a outros (incluídos aqui os órgãos públicos) um certo número de obrigações positivas". No campo dos direitos políticos, a liberdade das pessoas ganha em autonomia, tendo como consequência, "(...) a participação cada vez mais ampla, generalizada e frequente dos membros de uma comunidade no poder político (ou liberdade no Estado)" (BALLESTEROS, 1996, pp. 41 e 52, destaques do autor).

A dialética entre homem (direitos individuais) e comunidade (direitos sociais), além de impor restrições ao Estado Absoluto e exigir providências do Estado Liberal, densifica a responsabilidade sincrônica nas pessoas humanas em convivência, operando-se uma tímida solidariedade, ${ }^{20}$ a qual vai assumir sua essência com a terceira geração de direitos do homem, na qual os direitos ambientais terão uma destacada contribuição na construção da responsabilidade diacrônica, conforme será desenvolvido no item seguinte.

\section{A HUMANIDADE, A RESPONSABILIDADE DIACRÔNICA E OS DIREITOS (INTRA) - DEVERES (INTER) - GERACIONAIS ${ }^{21}$}

Para não esticarmos demasiadamente o raciocínio sobre as gerações de direitos humanos iniciado no item anterior, principia-se pela terceira geração desses e suas (prováveis) consequências ao nível da responsabilidade (diacrônica) e do direito (intrageracional) - dever (intergeracional). O traço marcante desta

\footnotetext{
${ }^{19}$ Justamente no contexto do Estado Absoluto ocorreram as reivindicações pelos chamados "direitos de liberdade", os quais, segundo Bobbio (2004, p. 41, destaques do autor), “(...) tendem a limitar o poder do Estado e a reservar para o indivíduo, ou para os grupos particulares, uma esfera de liberdade em relação ao Estado”.

${ }^{20}$ Castanheira Neves (2010a, p. 334) esclarece a timidez desta solidariedade ensejada pelos direitos individuais e coletivos (os últimos no sentido de pessoas identificáveis reunidas por interesses individuais comuns, o que, no Brasil, aproxima-se da noção de direitos coletivos em contraponto a de direitos difusos): “(...) o que se diz solidariedade entre os membros do mesmo grupo e nas respostas sociais às reivindicações dos grupos - as soluções dos conflitos sociais - não tem, num caso, fundamento ético, mas justificação tática (a pessoa, enquanto tal, de cada membro do grupo é indiferente) e, no outro caso, é apenas o resultado de uma luta de forças (no conflito social não vence necessariamente o que tem a seu favor a justiça, mas o que mobiliza maior poder social)".

${ }^{21}$ Segundo Weiss (1989, p. 21, nota 18), o termo intergeracional diz respeito às relações entre (diferentes) gerações e o intrageracional refere-se às relações entre membros de uma (mesma) geração, como a geração atual.
} 
terceira geração de direitos do homem é a concreta solidariedade, sobretudo naquela franja mais divulgada, cuja cidadania jurídica fora apenas há pouco reconhecida: o direito do (e também ao-) ambiente (e que especialmente nos interessa aqui). Esses direitos constituem as "condições de possibilidade dos direitos anteriores" (direitos anteriores que são as duas primeiras gerações de direitos humanos apresentadas na seção anterior), já que explicitam “(...)'as condições físicas e biológicas que tornam possível’ os direitos das gerações anteriores” (BALLESTEROS, 1996, pp. 24-25), devendo-se voltar os olhos para o direito à sustentabilidade em condições dignas de vida enquanto consequência dos pressupostos ecológicos, classificando tal fenômeno como "solidariedade diacrônica" pela ênfase depositada na temporalidade, nas gerações futuras.

Segundo Ballesteros, os direitos ambientais como direitos humanos de terceira geração além de permitirem a tomada de consciência da ação humana na utilização dos recursos naturais, podem eliminar as tensões existentes entre os direitos de primeira (implicadores de uma redução da atuação estatal) e de segunda geração (implicadores, por sua vez, de uma maior intervenção do Estado). O decisivo para esse autor não seria mais o papel desempenhado pelo mercado ou pelo Estado, e sim "a responsabilidade pessoal e social", que através da solidariedade permite a defesa dos direitos daqueles que ainda “(...) não são atualmente autoconscientes e livres, como as gerações futuras" (BALLESTEROS, 1996, pp. 24-25). ${ }^{22}$

Para além da responsabilidade de cada pessoa perante a outra, o tema desta seção instaura um marco, que decorre da concreta conscientização daqueles efeitos transtemporais (mencionados acima na introdução), a saber: a instauração de relações ético-jurídicas intergeracionais. Trata-se da tríade ética - responsabilidade gerações futuras [relações diacrônicas]. ${ }^{23}$ Nesse cenário rebentam novos problemas e, logo, alterações nas condições ordinárias de imputabilidade ética, ${ }^{24}$ que decorrem cada vez mais de ações aparentemente inócuas, pois, quando praticadas por muitos indivíduos, de forma independente, não pré-ajustadas e (mesmo) sem intenção lesiva, podem produzir coletivamente uma significativa quantidade de danos (KERNOHAN, 2000, p. 343). São os denominados accumulative harms, muitas vezes desencadeadores de danos ambientais (não só, mas

\footnotetext{
${ }^{22}$ Capella (1996, p. 49) faz duas importantes observações neste âmbito: (i) a terceira geração não se limita a realizar apenas a liberdade ou a igualdade entre os seres humanos, mas também a solidariedade, “(...) ou melhor, em outros termos, a igual liberdade para todos os seres humanos do planeta, presentes e futuros", portanto (ii) essa terceira geração não implica uma ruptura com as gerações de direitos humanos anteriores, mas sim o desenvolvimento integral dos direitos nelas contidos em face das novas necessidades históricas. Por fim, adianta-se (conforme será mencionado a frente) que as gerações futuras não são titulares de quaisquer direitos no sentido técnico do termo, pois, nas palavras de Heller (2010, p. 30), “(...) a justiça intergeracional não pressupõe direitos existentes enquanto direitos potenciais são apenas projeções ou metáforas com pouca relevância, pois não são obrigatórios/vinculantes".

${ }^{23}$ Ressaltamos que a forma da responsabilidade diacrônica aproxima-se em muito (mas não se equipara) do "modelo de transmissão de um patrimônio comum” de Ost (1995a, pp. 338-350) - articulado em torno de quatro conceitos-chave, (i) a responsabilidade, (ii) as gerações futuras, (iii) o patrimônio e (iv) a humanidade.

${ }^{24}$ Destaca Ost (1995a, p. 305) vários traços do agir moral que sofrem uma reviravolta, colocando-se em causa as "condições habituais da imputabilidade ética", i.e.: (i) o vínculo entre uma ação individual de alcance mínimo e um "efeito coletivo gigantesco"; (ii) "a relação de proximidade local e temporal entre um ato e as suas consequências"; (iii) o conhecimento anterior dos possíveis efeitos negativos daquela ação.
} 
sobretudo) futuros, podendo ser provocados pelas gerações anteriores e afetar as futuras. Danos esses de efeitos intergeracionais, e que, ao se ligarem aos comportamentos humanos, estabelecerão "novas responsabilidades". ${ }^{25}$

Um primeiro elemento dos danos acumulativos (também um dos novos focos do comportamento ético contemporâneo) é a ação coletiva, i.e., o somatório de condutas individuais que, praticadas por um grande número de pessoas, acarreta sérios danos ao meio ambiente e aos seus elementos. Isso faz com que o ato individual prescinda dos resultados da ação coletiva, v.g., ao se despejar num rio determinado líquido contaminante - o que seria irrelevante em pequenas quantidades - não se leva em consideração a multiplicidade de sujeitos que praticam a mesma conduta (LORENZETTI, 2010, p. 27). Em segundo lugar, surge a questão da imputação justa de uma responsabilidade por tais atos, o que Ost (1995a, p. 303) questiona: “(...) como atribuir responsabilidades e impor soluções, quando, é mais do que evidente, que o 'efeito estufa' resulta da ação cumulativa de centenas de milhares de comportamentos individuais não deliberados?”. E acrescentaríamos: comportamentos esses estimulados pela própria sociedade através das instituições orientadas pelos agentes econômicos hegemônicos, como não anunciar aqui a possível tragédia de uma humanidade guiada pelo american way of life ...

Há uma vasta gama de danos de grandes dimensões decorrentes de cotidianas condutas individuais executadas por uma massa de indivíduos, v.g.: as chuvas ácidas, a destruição da camada de ozônio, a sobrepesca, a caça predatória e as poluições atmosférica, hídrica e do solo. Em um determinado contexto, supõe-se que três elementos entrem em contato e formem uma substância nociva, ${ }^{26}$ seria justo imputar os danos desta composição à fábrica que emite apenas um desses elementos, não danoso se isoladamente considerado $(\mathrm{C})$, mas que, em sinergia com os elementos A e B, torna aquela nociva? (KERNOHAN, 2000, pp. 348-349). E se cada um desses elementos fosse fruto de fábricas diversas (i.e., as fábricas X, Y e Z emitem os respectivos elementos A, B e C)?

Nítidas são as dificuldades de estabelecimento do nexo causal entre cada ação individual executada e o dano global provocado. A causalidade entre a ação individual passada e o dano ao ambiente a posteriori enfrenta problemas como: (i) a limitada análise dos efeitos da ação humana no tempo e no espaço, a qual “( ... ) prescinde das consequências mediatas que agem em médio e longo prazo, assim como das que se produzem por interação com outras condutas e com fatores naturais" (LORENZETTI, 2010, p. 27); (ii) os limites de poluição geralmente determinados em função de cada poluente, não se levando em conta os efeitos somativos, aditivos e sinérgicos ${ }^{27}$

\footnotetext{
${ }^{25}$ Segundo Ost (1995a, p. 308) estabelece-se “(...) um vínculo, pela ideia de responsabilidade, entre um comportamento e os seus efeitos". Quanto à necessidade de novas responsabilidades, Ricoeur (1992, p. 281) menciona "[...] des maitrises nouvelles correspondent des responsabilités nouvelles".

${ }^{26}$ Por exemplo, considere a substância danosa de fórmula A2 B3 C4. Sabe-se que ela é constituída pela combinação de elementos que estão separados no meio ambiente, a saber: A - um subproduto da própria vida biológica; B - encontrado naturalmente em abundância na atmosfera; e C - uma externalidade produzida por uma obsoleta fábrica.

27 "Somativos" por serem resultado de simultâneas ou sucessivas quotas individuais de mesma composição (danos como problema de ordem quantitativa), i.e., as massivas emissões de poluentes do tráfego rodoviário, a emissão de clorofluorcarbonetos e os
} 
entre as inúmeras espécies de substancias artificiais e naturais que se misturam e se acumulam no ambiente; (iii) o fator do contexto local (suas particularidades), não raras vezes é negligenciado, podendo oferecer dificuldades na escolha dos padrões de poluição (geralmente universais); ${ }^{28}$ (iv) a influência de fatores físico-químicos naturais ou artificiais podem alterar as reais capacidades de absorção e de assimilação de cargas poluentes pelo meio ambiente.

Tal como a pessoa é sujeito de responsabilidade (sincrônica), a humanidade (enquanto síntese de geraçoes passadas, presentes e futuras) assume uma (talvez a principal delas) responsabilidade: a salvaguarda das condições de existência da vida sobre a Terra. Gethmann lembra que a preocupação ética com as gerações futuras não é uma novidade, fazendo menção ao imperativo prático de Kant, ${ }^{29}$ cujo reconhecimento recíproco da humanidade em suas pessoas e dentro de cada uma das outras como pessoas da comunidade instituída, abarcaria no "Reich der Zwecke” “(...) as já não e as ainda não pessoas vivas” (GETHMANM, 1994, p. 189). ${ }^{30}$ Também ressoam neste âmbito a filosofia da biologia e o princípio da responsabilidade de Jonas, cujas considerações pelos homens futuros deveriam passar pelas ações práticas, falando de uma ética voltada para o futuro, segundo uma dimensão cósmica marcada pelas perigosas intervenções do homem nas bases da vida. ${ }^{31}$

Notamos que é imprescindível cravar aqui a inexistência de direitos por parte das gerações futuras, por isso nos limitamos a falar em responsabilidade diacrônica, na qual é possível apenas se falar em obrigações ou deveres para com aquelas. Portanto, ao se falar em direitos, automaticamente estaremos a referir às relações jurídicas de natureza intrageracional - direitos [intra].

Visser't Hooft busca interpretar a "noção de uma ética entre gerações" através da ideia de desenvolvimento sustentável, reconhecendo que o amplo consenso em torno dos recursos ecológicos essenciais faz do "princípio de uma tomada em consideração equitativa dos interesses de longo prazo" um ponto de partida, ainda no plano moral (VISSER'T HOOFT, 1991, pp. 31-32) Portanto, no plano de uma possível responsabilidade, esse jurista refere-se ao "dever de equidade ecológica para as gerações futuras" e uma "noção de equidade entre gerações", onde inicialmente os homens do futuro seriam considerados como sujeitos morais pelos homens do presente, sob um princípio diretor: o da igualdade de estatuto entre os interesses futuros e contemporâneos em relação a certos recursos ecológicos fundamentais (VISSER’T HOOFT, 1991, pp. 32-34).

despejos de esgotos domésticos. Os "aditivos" resultam de complexas conexões de quotas individuais de ações diversificadas, e os efeitos "sinérgicos" da combinação de elementos ou substâncias diferentes no ambiente de forma que, quando se encontram, geram um efeito, em regra, mais nocivo que o somatório dos efeitos das mesmas substâncias quando isoladas (RONZANI, 1992, pp. 45,46 e 47$)$.

${ }^{28}$ Segundo Ost (1995a, p. 129), cujas “( ... ) doses máximas são fixadas in abstrato, sem ter em conta as especificidades locais do meio nem as predisposições individuais".

29 "Age de tal maneira que uses a humanidade, tanto na tua pessoa como na pessoa de qualquer outro, sempre e simultaneamente como fim e nunca simplesmente como meio" (KANT, 2007, p. 69).

30 „[...] durch die geforderte wechselseitige Anerkennung als Personen gebildete Gemeinschaft, das ,Reich der Zwecke‘ umfaßt somit auch die nicht mehr und die noch nicht lebenden Personen" (GETHMANM, 1994, p. 189).

${ }^{31}$ Para mais detalhes sobre isso, cfr.: RICOEUR, 1992, pp. 304-319. 
Posteriormente ele defende um "dever de justiça distributiva sobre o plano intertemporal", posto que essa exigisse, por consequência, que as chances de vida das gerações futuras não sejam diminuídas (VISSER'T HOOFT, 1991, p. 34). Boff (2003, p. 16), por sua vez, afirma a necessidade de se constituir "um pacto", não mais fundado sob a razão ilustrada, mas no pathos, atraindo e harmonizando valores como os da sensibilidade humanitária, da inteligência emocional, da compaixão, do cuidado, das responsabilidades social e ecológica, da solidariedade geracional, “(...) atitudes essas capazes de comover as pessoas e movê-las para uma nova prática histórico-social libertadora. Urge uma revolução ética mundial”.

A ideia de humanidade (sujeito da responsabilidade diacrônica) parte da proposta kantiana da "república universal”, associada à concepção de patrimônio (objeto dessa responsabilidade), e procura "(...) inscrever a transmissão numa linha virtualmente infinita, tanto do lado dos ancestrais como do dos descendentes" (OST, 1995a, p. 339). Importante lembrar que as gerações futuras, as beneficiárias dessa responsabilidade, não se reduzem as duas do "modelo doméstico", englobam as "gerações futuras longínquas", o que implica privilegiar as "exigências de preservação no longo prazo (que são precisamente as exigências da natureza, se quisermos utilizar esta forma de expressão), às facilidades do consumo no curto prazo" (OST, 1995a, p. 338). ${ }^{32}$ Assim como a pessoa é responsável por ser pessoa, a humanidade também o é, sendo a pessoa o núcleo de todo o modo-de-serhumano, valor indeclinável de qualquer instituição humana (e, sobretudo, do direito), o meio ambiente enquanto condição de existência daquele núcleo inviolável será o objeto de uma responsabilidade de toda a humanidade (seja ela presente ou futura). Segundo essas ideias, Ost (1999, p. 433) afirma:

(...) é do seio de uma Humanidade diacrônica que se desprende a nossa humanidade singular; é no centro de uma comunidade transtemporal que se experimentam os nossos direitos e os nossos deveres; é a partir de uma perspectiva intergeracional que se coloca a questão do justo e do direito (...).

Como resulta da coimplicação entre dignidade humana e responsabilidade o "princípio do mínimo existencial", ${ }^{33}$ na responsabilidade diacrônica fala-se num "mínimo existencial ecológico", ${ }^{34}$ scilicet, de um estrato ecológico da dignidade da pessoa humana. Nele o direito fundamental ao meio ambiente ecologicamente equilibrado tem um “(...) relevo especial na missão de tutelar e de desenvolver o princípio da dignidade da pessoa humana ou como desdobramento imediato da corresponsabilidade intergeracional" (SAMPAIO, 2003, p. 98).

\footnotetext{
${ }^{32}$ Noção mais alargada de gerações futuras que é retirada do modelo (classificado por Ost como) "hercúleo" de Jonas, consistindo em uma "(...) descendência abstrata, que afetam necessariamente as consequências longínquas e cumulativas das ações presentes" (OST, 1995a, p. 340).

${ }^{33}$ Através do mínimo existencial procura-se assegurar a cada pessoa o gozo e o acesso equitativo aos bens e serviços indispensáveis “(...) para que verdadeiramente possa existir como pessoa - que lhe assegure o 'seu necessarium vitae, mas também [o] seu necessarium personae', o quantum de ter de que precisa para poder ser -, o que postula o sincero compromisso da comunidade (máxime, através do Estado) no dever de corresponsabilizante solidariedade que assim se enuncia” (BRONZE, 2010, pp. 485486).

${ }^{34}$ Com inequívoca guarida constitucional na Constituição da República Federativa do Brasil (art. 1. ${ }^{\circ}$ III, combinado com o art. 225).
} 
Em consonância à dilatação da responsabilidade entre as gerações, a dimensão das relações éticas também se amplia e se condensa em um feixe de compromissos solidários dialeticamente pessoais-sociais, privados-estatais e ético-jurídicos fundados sobre a dignidade da pessoa humana. Para além disso, todo esse quadro implica uma "ética da responsabilidade solidária", a qual não se prenda "cronofagicamente no presente e antes integre adequadamente o futuro - 'o cuidado do futuro' - , assumindo-se como verdadeira ética aberta ao futuro, e mesmo ao futuro longínquo (...)” (BRONZE, 2012, pp. 200-201; BRONZE, 2010, pp. 519-520).

Trata-se aqui da construção de sentido do direito, sujeito ao Zeitgeist, o que permite na atualidade apontar o patrimônio natural-cultural e suas respectivas qualidades como condições do ser-aí-pessoa e do vir-aser-pessoa (as gerações futuras). O modelo de "transmissão de um patrimônio comum” [da humanidade] desenvolvido por Ost bebe da "regra de ouro", "o extremo último da exigência ética: restabelecer a igualdade na interação, mesmo quando o contexto é totalmente dissimétrico" (OST, 1995a, pp. 341-342). O homem, em seu compromisso comunitário de pessoa por si e para com os outros, ${ }^{35}$ em cujas relações e interesses o meio ambiente com seus elementos apresenta-se como prius indeclinável, que não pode ser negado àqueles ainda não nascidos.

A responsabilidade diacrônica fundamenta-se na "solidariedade diacrônica", integradora dos interesses (não direitos) das gerações futuras, como nos ensinou há pouco Ballesteros. Visser’t Hooft (1991, p. 36) nos fala do problema de fundo de uma justiça distributiva no plano intertemporal (no tocante aos recursos ecológicos) com o fito de se garantir de forma durável este "mínimo vital". ${ }^{36}$ Trata-se aqui de uma relação de reciprocidade assimétrica (entre diferentes gerações), pois ela não se fundamenta em direitos ${ }^{37}$ e sim em obrigações sem direitos correspondentes, segundo fundamentação de Heller (2010, p. 25).

As três condições constitutivas e de emergência da dimensão ética do direito (já desenvolvidas supra) serão revisitadas aqui sob o prisma das relações ético-jurídicas entre gerações. Quanto à "condição mundanosocial" (1.a), Loureiro (2010, p. 17) ao se referir apenas à primeira delas (a condição mundanal) adverte que o direito se torna também “condição de possibilidade de existência, sem a qual não há coexistência”, e cuja tradução jurídica consubstancia-se num conjunto de deveres (incluindo obrigações) para com as gerações vindouras ou futuras. Consubstanciada na "pluralidade humana na unicidade do mundo", permite-se afirmar que, sendo o mundo apenas um (o meio ambiente global, o planeta Terra) e a diversidade humana plural, a humanidade está

\footnotetext{
35 “(...) significa responsabilidade perante a pessoa e a sua humanidade, mas também responsabilidade da pessoa perante a humanidade do outro" (GARCIA, 2007, p. 481). Segundo Ost (1995a, p. 342), “(...) o respeito da minha própria humanidade passa pelo respeito da de outrem (mesmo morto, futuro ou totalmente dependente) (...) A reciprocidade não é, portanto, da ordem do dar a quem dá, uma vez que o contexto é assimétrico; mais fundamentalmente, ela recorda que o homem privado de humanidade não é nada”.

36 "Le problème qui est à la base de tout, c'est de garantir de façon durable un 'minimum vital”" (VISSER'T HOOFT, 1991, p. 36).

37 "Nós temos obrigações com as futuras gerações, mesmo responsabilidades para corresponder às expectativas daquelas obrigações, porém as futuras gerações não podem ter direitos. Não há e não pode haver reciprocidade simétrica entre nós e qualquer futura geração e, de fato, não há reciprocidade alguma" (HELLER, 2010, p. 25).
} 
inserida (jamais equiparada) na biosfera. Ideia também sufragada por Ricoeur (1991, p. 273) que - ao discorrer sobre a série de mutações ocorridas nas sciences de la vie, em especial, no âmbito da biotecnologia e engenharia genética - destaca os dois horizontes da vida: o primeiro do homem como portador de história, e no fundo desse está o segundo, a biosfera. ${ }^{38}$

Isso remeterá àlgumas notas imprescindíveis no tocante ao tema do desenvolvimento sustentável. ${ }^{39}$ Como se sabe, a concepção mais divulgada desta ideia-motora parte da isonômica consideração dos três elementos envolvidos (sociedade - economia - biosfera/meio ambiente), isto permite a chamada "perversão" do conceito, o que Winter (2009, p. 5) desvalora como "o conceito fraco de sustentabilidade" ${ }^{40}$ Nessa valoração isonômica dos elementos não é de se espantar que o meio ambiente (a biosfera) seja preterido em relação à sociedade, e esses dois à economia. ${ }^{41}$

Contudo, Bosselmann (2008, p. 30) nos adverte do perigo de se sopesarem os três elementos dentro de uma perspectiva em que os limites são sempre aferidos segundo o bem-estar humano, ignorando-se o bem-estar de outras formas de vida, sendo que "(...) o dilema, claro, é que nós não podemos sobreviver sem preocupação pelo bem-estar da vida como um todo. Esta é a dura realidade que descobrimos através da ecologia”. Frente isso, Winter (2009, p. 4) propõe o conceito de "sustentabilidade forte", no qual a biosfera é o fundamento, sendo a economia e a sociedade os dois pilares, "(...) pois a biosfera pode existir sem os humanos, mas os humanos certamente não podem existir sem a biosfera".

Em relação à condição humana-existencial (cfr. acima), ela inclui a transferência de um patrimônio natural-cultural para as gerações futuras. Primeiramente, em relação ao objeto dessa transmissão (o objeto da própria responsabilidade diacrônica), ele é o "híbrido natureza-cultura", a constituição complexa do meio, instituição complexa transtemporal (identificável no presente, carregando as marcas do passado e se destinando ao futuro) e translocal (para lá das divisões e limites administrativos dos Estados e da noção jurídica tradicional de propriedade) que articula sujeito e objeto, privado e público, local e global, presente, passado e futuro (OST, 1995a, p. 354). A noção de meio (dialética homem-ambiente) é escolhida por Ost (1995a, pp. 351-353), primeiramente porque ele não é mero objeto e tampouco sujeito, segundo porque as respostas adequadas à

\footnotetext{
${ }^{38}$ Capra (2005, p. 223) nos lembra (...novamente poderia ser este mais um dos itens na lista da raposa sobre os esquecimentos humanos...) que “(...) no contexto da globalização, há duas grandes comunidades às quais todos nós pertencemos: todos nós somos membros da raça humana e todos fazemos parte da biosfera global”.

${ }^{39}$ Visser't Hooft (1991, pp. 31-32) considera que a noção de desenvolvimento sustentável resultante do relatório Brundtland (1987) introduziu uma noção de "ética entre gerações".

${ }^{40} \mathrm{O}$ preocupante do ponto de vista das gerações futuras é que, segundo Winter (2009, p. 5), “(...) como a biosfera (embora objetivamente flexível a certa medida) não pode refletir nela própria e no seu relacionamento com os humanos, e como o conceito dos três pilares é imprudente e descompromissado, ele leva facilmente a compromissos simulados. Sacrifícios da natureza, utilizados para o destaque na economia a curto prazo ou para interesses sociais, podem tornar-se destrutivos para a própria economia e sociedade, a longo prazo".
} 
problemática ambiental exigem a superação da distinção entre direito público e direito privado, entre esfera pública e esfera privada. ${ }^{42} \mathrm{O}$ conceito de patrimônio aqui empregado origina-se de uma noção doméstica e privada, parte do contexto do domus da tradição romana, dos bens transmitidos pelo pater família. ${ }^{43}$

Em relação à forma de se transmiti-lo às gerações futuras, ela passa pela tutela do mesmo hoje e concretiza-se com a traditio àquelas, desde que em condições mínimas de vivência. Ost (1995a, p. 328, nota 48) invoca o paradigma de responsabilidade utilizado por Jonas (a saber, o de manutenção dos pais em relação aos filhos) para justificar tal relação dialética entre as gerações na proteção e transmissão do patrimônio comum. Essa analogia esclarece que a obrigação de manutenção unilateral e incondicional dos pais [as gerações atuais] para com os seus filhos "menores" [as gerações futuras] transforma-se em dever condicional e recíproco de alimentação quando esses atingem a idade adulta [portanto, quando dialeticamente se transformam na geração atual, os filhos-no-passado-pais-no- presente assumem também a mesma obrigação de manutenção unilateral e incondicional para com os que ainda virão]..$^{44}$ Trata-se do mesmo exemplo mencionado por Heller (2010, p. 22) ao falar "do assim chamado 'direito da criança", rectius, da ausência de reciprocidade simétrica entre os filhos menores e seus pais. ${ }^{45}$

Outras formas análogas são utilizadas por Weiss. ${ }^{46}$ Uma delas é a de que os arrendatários (tenants) possuem o direito ao uso razoável da propriedade, mas precisam devolvê-la em boas condições para que os futuros arrendatários também a utilizem. A segunda advém da instituição do charitable trust, ${ }^{47}$ na qual os beneficiários do patrimônio (administrado e preservado pelos curadores) têm o direito de desfrutar dos

\footnotetext{
${ }^{41}$ Segundo Winter (2009, p. 7), “(...) por um julgamento não adequado sobre a amplitude do peso da natureza, o conceito propaga a equivalência dos três pilares, que conduz a fugir do trabalho conceitual de atribuir à natureza o peso adequado".

${ }^{42}$ Ost (1995a, pp. 351-353) faz menção expressa às relevantes contribuições para o direito ambiental de institutos jurídicos como a "dominialidade" do direito público; "as coisas comuns", "o usufruto, a utilização e as servidões" do direito privado. Dessa forma, cabe lembrar o reconhecimento, especialmente pela doutrina e jurisprudência ambientais nacionais, das obrigações de instituir, regularizar e manter as áreas de reserva legal florestal e as áreas de preservação permanente como obrigações de natureza jurídica propter rem, cfr. alusivamente as seguintes decisões expressas nesse sentido: Tribunal de Justiça do Estado de São Paulo, Câmara Especial de Meio-Ambiente. Apelação com revisão n. ${ }^{\circ}$ 4583925100. Relator Desembargador Samuel Júnior, j. 25.09.2008, p. 03.10.2008; Tribunal de Justiça do Estado de São Paulo, Câmara Especial de Meio-Ambiente. Apelação com revisão n. ${ }^{\circ}$ 626.388.5/2-00. Relatora Desembargadora Regina Zaquía Capistrano da Silva, j. 13.11.2008, p. 01.12.2008.

${ }^{43}$ Tanto que Ost (1995a, p. 356) faz questão de esclarecer que os bens integrados nesse patrimônio são provenientes de um "passado vivo", o qual “(...) pela operação da memória viva e da tradição em ato, o passado do patrimônio é revivificado e surge como um recurso para o futuro".

${ }^{44}$ Ao tratar da ideia de "um ativo que deriva do passivo", no tocante a sua proposta de "patrimônio" para o "híbrido naturezacultura”, Ost (1995a, p. 370) diz expressamente que "(...) quando se trata da sobrevivência do meio e quando se trata, a partir de agora, de um 'patrimônio comum', a solidariedade impõe-se como uma obrigação incondicional”.

${ }^{45}$ Heller (2010) também desenvolve aqui uma ideia paralela entre essa responsabilidade assimétrica dos pais pelos filhos e a responsabilidade (também assimétrica) das gerações presentes pelas futuras, e ambas como manifestações de obrigações sem direitos correspondentes.

46 "Many useful analogies in domestic legal systems set forth rights of acess to and use of property, which are coupled with obligations to conserve that property” (WEISS, 1989, p. 17).

${ }^{47}$ Segundo Goyos Júnior (2006, p. 96), trata-se de um "instrumento utilizado para efetivar a administração de bens com fins filantrópicos".
} 
benefícios desse, mas não têm o direito de dissipá-lo em prejuízo dos futuros beneficiários. Por fim, a última analogia é com o direito de uso de parques nacionais, nos quais são exigidas obrigações no sentido de não profanálos em prejuízo dos futuros visitantes (ou usuários).

Um ponto comum a todas essas analogias a respeito da transmissão do patrimônio natural-cultural para as gerações vindouras é a "transitividade" desta "relação assimétrica" entre gerações passadas e futuras. ${ }^{48}$ Ao identificar essa diferença, Ost alarga temporalmente o modelo contratual daquela - e afasta o aspecto recíproco das prestações equivalentes, portanto a reciprocidade negocial, cfr. alguns aspectos a seguir, nomeadamente na nota 59- , pois na transmissão a relação entre os envolvidos é marcada pela transitividade. Parafraseando o jusfilosófo belga, diríamos “(...) na transmissão, A [geração passada] dá a B [geração presente] que, por sua vez, dará a C [geração futura] (...)”, pois é assegurada uma determinada igualdade entre as relações entre A, B e C, mas “(...) é por conseguir mobilizar a duração que a transitividade equilibra as prestações” (OST, 1999, p. 434). Não seria essa duração da existência e da qualidade do patrimônio natural-cultural na transitividade entre as diferentes gerações o núcleo da responsabilidade-projeto de Ricoeur, da proposta de Ost ou da teoria da equidade intergeracional de Weiss? Essas ideias são frequentes nas culturas humanas, podendo-se vislumbrar as raízes da (solidariedade-) responsabilidade diacrônica, bem como a transitividade da transmissão, no adágio queniano (também atribuído ao Cacique Seattle): "Nós não herdamos a terra dos nossos pais, nós a tomamos emprestada dos nossos filhos". ${ }^{49}$

Além disso, a proposta de Weiss requer um estrato mínimo de equidade entre gerações, devendo as gerações atuais preservar e cuidar dos bens ambientais da melhor forma possível, não violando o piso mínimo (minimum floor) de quantidade, qualidade e acessibilidade recebido de seus antecessores. ${ }^{50}$ Weiss (1989, p. 22) apresenta dois modelos extremos que definem as fronteiras da equidade intergeracional: (i) o modelo preservacionista e o (ii) modelo opulento. O primeiro (i) implica a impossibilidade da geração presente consumir os recursos naturais, pois ele "(...) salva todos os recursos para as futuras gerações e preserva o mesmo nível de qualidade em todos os aspectos do ambiente”, i.e., “(...) as gerações futuras beneficiariam-se às custas das gerações

\footnotetext{
${ }^{48}$ Relação assimétrica porque não se funda em direitos exigiveis bilateralmente, até porque "violar os direitos dos outros exige sanções, principalmente sanções jurídicas. Ao menos, este é modelo dos direitos e das obrigações dos cidadãos modernos que os Estados e as sociedades estão comprometidos/obrigados a tornar acessível” (HELLER, 2010, p. 24). Além disso, consistindo a futura geração de "completos estranhos" e ao partimos da concepção de que ela tem direitos, caso os violássemos, "(...) podemos também dizer que seremos punidos se os violarmos? Mas quem irá punir? Não serão as futuras gerações, pois elas não existem” (HELLER, 2010, p. 26).

${ }^{49}$ Significativo também é o provérbio comum aos povos do deserto do Saara, que diz "bebe do poço e deixa teu lugar para outro", segundo um contexto de "toda uma cena do deserto, onde homens, rebanhos e bando de animais de carga têm que matar a sede num pequeno charco” (ORTEGA Y GASSET, 2004, p. 29).

${ }^{50}$ Embora Weiss (1989, pp. 24-25; 1990, p. 200) não desenvolva as minúcias desses elementos e nem as consequências desta proposta de piso mínimo dos recursos naturais na equidade intergeracional, chega a dizer que ela possui "premissas implícitas" de uma curadoria, procuradoria e arrendamento, voltadas à conservação do "espólio", não podendo ser dissipado, ficando equitativamente disponível para aqueles que virão depois, scilicet, as gerações futuras.
} 
anteriores" (WEISS, 1989, p. 23). Já o segundo modelo (ii) implica justamente o contrário, aqui a geração atual consumiria os recursos naturais e culturais sem limites, produzindo o máximo de riqueza possível, sob os argumentos de que não há certeza de que as gerações futuras existirão ou de que a melhor forma de maximizar a riqueza para elas é elevando o consumo ao máximo. Problemas como as condições de inabitabilidade de certos locais pelas mudanças climáticas, perdas irrreversíveis de diversidade biológica e de recursos renováveis ou ainda as contaminações do ambiente por lixos radioativos ou perigosos, tornando as áreas afetadas inapropriadas para o uso ou habitação, são todos eles absolutamente indiferentes para o modelo opulento, pois este “(...) não leva em consideração as degradações do planeta a longo-prazo" (WEISS, 1989, p. 23).

A condição ética (a terceira delas, cfr. supracitado) implica o reconhecimento de cada geração em face da outra (presente, passada ou futura), através da responsabilidade diacrônica. Responsabilidade a respeito das gerações futuras que passa inicialmente pela "preocupação" ética da geração atual, necessitando de um regime jurídico para a transmissão do patrimônio natural-cultural que implique “(...) uma moderação, tanto nas subtrações como nas rejeições, a fim de garantir a igualdade das gerações no acesso a recursos naturais de qualidade equiparável" (OST, 1995a, p. 352).

O mundo único que incluí todos os demais (natural, social e cultural) exige da responsabilidade diacrônica um feixe de obrigações e de deveres diferenciados na proteção da "matéria, da vida humana e não humana”. Entre os seres humanos (incluídas aqui as presentes gerações humanas) há um dever simétrico de tutela e transmissão do patrimônio ambiental-cultural (OST, 1995a, p. 340), ${ }^{51}$ portanto as relações entre (as gerações do...) passado- (...do) presente- (...e do) futuro são marcadas por uma dialética que permite inserir nesta questão “(...) uma dose de compensação pelos sacrifícios consentidos, equilíbrio inerente à própria ideia de justiça”, “(...) reintroduzindo (...) uma certa dose de simetria e de equilíbrio próprio da justiça comutativa” (OST, 1995a, pp. 328 e 338). Mas entre o homem e os demais seres vivos, e dele com a matéria inorgânica, há um dever assimétrico de responsabilidade, embora Ost (1995a, p. 311) reconheça que não se deve perder de vista a "solidariedade de destino entre a matéria, o ser vivo e os seres humanos". ${ }^{52}$ Em razão do objeto da responsabilidade (a constituição complexa do meio) envolver o próprio destino de seus titulares e beneficiários diretos (a comunidade humana) e indiretos (a matéria inorgânica e a biosfera), destacam-se três tipos de justificação desta responsabilidade: (i) o interesse utilitário do homem na matéria (nos elementos abióticos), (ii) o dever assimétrico de respeito para com a vida (a comunidade biótica não-humana) e (iii) a obrigação de fazer valer o sentido do homem (a reivindicação

\footnotetext{
${ }^{51}$ Uma importante observação aqui é que entre a humanidade (entre as gerações) há um dever simétrico em função da relação ética existente, mas a responsabilidade de uma para com a outra é de ordem assimétrica em razão do tempo em que se colocam.

52 Pois não há razões ética-juridicamente sustentáveis para se falar em direitos dos animais ou dos seres vivos não-humanos, conforme bem frisa Ost (1995a, p. 313), o traço da responsabilidade é inexoravelmente humano, pois "apenas o homem, entre as criaturas vivas, tem acesso ao nível do sentido", ou seja, "não que as plantas e animais tenham direitos a fazer valer, mas que nós,
} 
de direitos dos homens). ${ }^{53} \mathrm{~A}$ assimetria de deveres neste modelo diacrônico decorre do núcleo irradiante da solidariedade, pois segundo Bayertz (2000, p. 86) "( ...) enquanto os direitos de liberdade são universais, as obrigações solidárias baseiam-se em particulares fundamentos".

Em sintonia com os dois princípios axiológico-normativos fundamentais da responsabilidade jurídica (cfr. já exposto inicialmente), seguem alguns apontamentos de seus correspondentes reflexos na responsabilidade diacrônica. Notamos que há uma consonância entre os três princípios da equidade intergeracional de Weiss ${ }^{54} \mathrm{e}$ os três princípios complementares destinados a assegurar a efetividade do "estatuto jurídico para o meio" de Ost. Primeiramente, trata-se do livre acesso de todos aos recursos genéticos por meio da pesquisa, desenvolvimento e propagação. O que vai de encontro ao terceiro princípio da equidade intergeracional, princípio da conservação do acesso, o qual determina para cada geração existente ou para todos os membros da mesma um mesmo acesso ${ }^{55}$ (concreto) aos recursos ambientais.

Weiss (1989, p. 45) toca aqui em um ponto crucial e previamente condicional aos desideratos da própria equidade intergeracional (e da responsabilidade diacrônica): a necessidade de diminuir as desigualdades socioeconômicas intrageracionalmente. ${ }^{56}$ Para suprir esta primeira condição do princípio da conservação do acesso, é imprescindível levar a sério, e sobretudo implementar, a colocação de Ballesteros (1996, p. 29) sobre a "hierarquia de necessidades" em relação às qualidades dos direitos e das gerações desses envolvidas, scilicet, o direito à alimentação das pessoas atuais em pior situação econômica é o primeiro direito. ${ }^{57}$ Já no campo energético, esse autor propõe a necessidade de se introduzirem energias alternativas, como a solar, pois além de não destruírem recursos não renováveis também não produzem resíduos. E, por fim, para realmente se garantir a

homens, tenhamos deveres a respeitar. Deveres assimétricos de responsabilidade, justificados simultaneamente pela vulnerabilidade dos beneficiários e pela necessidade de respeitar as simbioses biológicas, no interesse da humanidade inteira”.

${ }^{53}$ Dessa forma, Ost (1995a, p. 313) expõe os três tipos diferenciados de responsabilidade que envolvem as três esferas ("a matéria inorgânica, a biosfera, a comunidade humana") constituintes do meio (o "híbrido natureza-cultura"), "simultaneamente distintas e dialeticamente ligadas".

${ }^{54}$ Segundo Weiss (1990, p. 202), eles constituem a "base de um conjunto de obrigações e de direitos intergeracionais, ou direitos e obrigações planetários, que são portados por cada geração”. E ainda, segundo o seu pensamento, estão inseridos no contexto de reconhecimento de problemas intertemporais de horizonte longínquo (WEISS, 1989, p. 34).

${ }^{55}$ Com base em um abstrato "nível de acesso mínimo" (minimum level of access), assumido como padrão de igualdade, cuja primeira geração determinaria o mínimo absoluto daquele nível de acesso a ser transmitido às gerações sucessoras, implicando uma evitação da situação pior e o encorajamento do melhoramento das condições (ambientais) existentes (WEISS, 1989, p. 44).

${ }^{56}$ Weiss (1989) é explícita ao mencionar que os membros mais pobres devem ser assistidos pelos de melhores condições econômicas para conseguir um efetivo acesso aos bens ambientais e culturais. Isso tanto em nível interno (i.e., a classe mais favorecida economicamente auxiliando a menos favorecida em determinada sociedade) quanto externo (i.e., as nações mais abastadas ajudando as mais carentes). Para tal, é indispensável (i) fazer com que as camadas mais pobres da comunidade possam satisfazer suas próprias obrigações de conservação; e (ii) assegurá-las o acesso aos benefícios econômicos do legado deixado pela geração anterior. Também Ost (1995a, p. 320, e sobretudo, a sua conclusão intitulada de "o meio injusto") não deixa de lembrar a extrema pobreza como problema iminente a ser resolvido para a melhoria das condições de vida da geração presente, por conseguinte "(...) uma gestão mais racional das relações com o meio", sendo “(...) evidente, a justiça a respeito das gerações futuras (resultante de uma melhor preservação de recursos), passa por uma maior equidade em relação à humanidade presente”.

${ }^{57}$ Segundo Ballesteros (1996, p. 29): "Há uma hierarquia de necessidades, que começa pelas pessoas atuais em pior situação: o direito à alimentação é o primeiro direito, superior inclusive aos direitos das gerações futuras”. 
conservação do acesso a todos, faz-se imperativo um combate ao nível de consumo (sobretudo, mas não apenas) do Norte, o qual, por ser não universalizável nem desejável, ${ }^{58}$ deve ser contido, considerando que “(...) o fluxo de energia e materiais tem sido majoritariamente dos países pobres para os ricos" (ALIER, 1995, p. 77).

Em segundo lugar, Ost menciona "a regra de conservação", a qual reconhece a cada Estado a livre exploração dos recursos decorrentes de plantas e de animais, desde que assumam a "obrigação de resultado" de garantir a sobrevivência desses recursos ambientais. Proposta que compartilha do mesmo fundamento da sustentabilidade forte de Winter: os recursos naturais são as bases da vida, portanto pré-condições da própria existência humana. Neste contexto inserem-se os dois primeiros princípios da equidade intergeracional. A conservação das opções como primeiro deles implica, para cada geração, a exigência de se conservar a diversidade dos recursos básicos naturais e culturais, não podendo as gerações precedentes restringir ou esgotar injustificadamente as opções ambientais e culturais para as futuras gerações, ainda que para resolver os problemas ou satisfazer os valores das gerações presentes (WEISS, 1990, p. 202).

Já o princípio da conservação da qualidade caracteriza o dever (...mas também o direito de...) das presentes gerações de manter (...usufruir da...) a mesma qualidade ambiental para as gerações futuras. Segundo Weiss (1989, p. 38; 1990, p. 202), isto designa uma obrigação de se manter a qualidade do planeta, não o transmitindo em condições piores que as recebidas. Importante ressaltar que esse princípio não representa uma paralização do desenvolvimento social, pois ele não implica tornar o ambiente imodificável, tal qual o modelo preservacionista ${ }^{59}$-, o que seria inconsistente com o princípio da conservação do acesso aos benefícios do legado ambiental e cultural da geração atual. A terceira e última regra seria "o princípio de financiamento internacional", nos moldes da criação de "uma taxa sobre a comercialização de recursos genéticos", permitindo internalizar os custos da obrigação de conservação dos recursos ambientais (as externalidades negativas) nos produtos originários deles (OST, 1995a, pp. 384-385).

Neste âmbito serão contrastadas algumas últimas peculiaridades sobre a responsabilidade diacrônica em

\footnotetext{
${ }^{58}$ Nesse sentido já advertia Furtado (s.d., p. 75) com as seguintes palavras: "O custo, em termos de depredação do mundo físico, desse estilo de vida é de tal forma elevado que toda tentativa de generalizá-lo levaria inexoravelmente ao colapso de toda uma civilização, pondo em risco as possibilidades de sobrevivência da espécie humana. Temos assim a prova definitiva de que o desenvolvimento econômico - a ideia de que os povos pobres podem algum dia desfrutar das formas de vida dos atuais povos ricos - é simplesmente irrealizável".

${ }^{59}$ Parafraseando Viola (1987, p. 73), nós consideramos que: “(...) existe uma complexa tensão entre a justiça social (que pode implicar, valorizar a distribuição sobre a ecologia) [diríamos aqui a conservação do acesso para as gerações presentes] e o ecologismo (que pode implicar, valorizar a ecologia sobre a distribuição) [conservação da qualidade - e das opções - para as gerações futuras]". Weiss (1989, pp. 13-14) trata de algumas delas no item "acesso e uso discriminatório dos recursos", advertindo que a superestima da conservação dos recursos para as gerações futuras - no sentido do modelo preservacionista - poderia privar as gerações atuais do acesso e uso dos recursos naturais e culturais da Terra. Contudo, o agravamento das diferenças sociais seria também transmitido às futuras gerações, o que acabaria por afetar o meio ambiente de maneira mais significativa. $\mathrm{O}$ outro problema inerente ao acesso e uso discriminatório dos recursos está relacionado a um problema intrageracional, a necessidade de promover um acesso equitativo de todos os membros da geração atual aos bens ambientais e culturais, o que passa inexoravelmente pela solução das desigualdades econômico-sociais. Nesse sentido, cfr. também: WEISS, 1989, p. 42.
} 
face da responsabilidade sincrônica. Ost (1999, p. 433) salienta que a ideia de responsabilidade expõe toda a sua fecundidade quando inserida nessa "perspectiva diacrônica", pois se afasta da concepção contratual e deságua nas “(...) situações assimétricas entre parceiros marcados pela desigualdade das suas posições respectivas (adultos e crianças, ativos e inativos, poderosos e fracos, gerações presentes e gerações futuras...)". No campo dos direitos fundamentais ou humanos, a preservação do patrimônio comum da humanidade enquanto condição essencial de existência implica “(...) compreender melhor esta dimensão ética em termos de responsabilidade que de direitos” (OST, 1996, p. 207), pois é inegável que a relação [ético-jurídica] entre as gerações presentes e futuras seja de caráter assimétrico, “(...) todas as obrigações são para nós, todos os benefícios para elas", ou ainda, “(...) a responsabilidade por parte da primeira, o interesse por parte das seguintes" (OST, 1995a, pp. 340-341). Em razão desse caráter assimétrico, a responsabilidade diacrônica não pode limitar-se à moldura meramente contratual, cuja reciprocidade é a regra. ${ }^{60}$ Além disso, conforme nos fala Heller (2010, p. 28), quanto às liberdades, “(...) nós não podemos fazer mais para as futuras gerações na Terra do que manter a ideia prática, o testamento sugerido por Arendt, do direito de ter direitos (esse é o então chamado direito humano) e trabalhar nas nossas liberdades, as quais testamos aos nossos descendentes no nosso estado, cidade, cultura e mundo".

Outro importante aspecto é a passagem de uma responsabilidade-imputação a uma responsabilidademissão, já apontada por Ricoeur, Ost e Heller. Ricoeur (1991, p. 282) primeiramente chama a atenção para a tardia incorporação técnica da responsabilidade pela filosofia moral, condenando a sua confusão com outra categoria, a da imputação. Segundo ele, essa constituiria o procedimento por meio do qual se identifica o autor de uma ação e a responsabilidade procura a fonte de toda uma rede de circunstâncias que declaram ou designam um ou vários agentes humanos responsáveis. ${ }^{61}$ Ele destaca também que a responsabilidade começa a se projetar para o futuro, ${ }^{62}$ principalmente na era da tecnologia que demanda uma abertura para o futuro longínquo, que ultrapassa o plano das consequências previsíveis (RICOEUR, 1991, p. 282). ${ }^{63}$ Trata-se aqui, nas palavras do jusfilósofo francês, de partir de uma "ideia de uma missão confiada" e chegar a "responsabilidade como um fardo que se assume, como um peso tomado pelos ombros" (RICOEUR, 1991, p. 282).

Essa "responsabilidade-projeto" vai além de uma responsabilidade-imputação caracterizada pelas faltas do passado, "no sentido de uma missão assumida para o futuro" (OST, 1996, p. 208; OST, 1995a, p. 338; ou, segundo as palavras do próprio autor, cfr. RICOEUR, 1991, p. 282). Não seria aqui também o sentido do

\footnotetext{
${ }^{60}$ Por isso, acima foi traçada a transitividade como o caráter da transmissão (cfr. apontado anteriormente, no texto principal, um pouco antes da marcação desta nota), a forma pela qual o patrimônio natural-cultural passaria das gerações presentes para as gerações futuras. Neste aspecto, cabe invocar as palavras de Ost (1999, p. 434): “(...) a transitividade é para as situações assimétricas (seguramente as mais frequentes), aquilo que a reciprocidade é para as situações simétricas”.

${ }^{61}$ Também neste sentido, cfr. OST, 1995, p. 308.

${ }^{62}$ Razão pela qual Ost (1995a, p. 338) denomina-a como "responsabilidade-projeto".

${ }^{63}$ Segundo Ost (1996, p. 208), a responsabilidade deixa de ser compreendida no "(...) sentido de imputabilidade por uma falta eventualmente cometida em certo momento no passado" e assume-se como "(...) uma missão assumida para o futuro”.
} 
comprometimento do futuro pela promessa de que nos fala Ost, scilicet, a instituição da promessa como o comprometer o futuro? A promessa é o autocomprometimento normativo a algo, "ela compromete o futuro ao comprometer o promitente; este arrisca aí algo de si mesmo sob o regime da auto-obrigação" (OST, 1999, p. 206, destaques do autor). Por fim, Heller (2010, pp. 27-28) nos fala de uma "responsabilidade prospectiva", quando “(...) estivermos encarregados de algo, assim como um capitão está encarregado de sua tripulação e dos passageiros. Responsabilidade planetária significaria, assim, que estou no comando do habitat humano em geral e no comando do futuro da raça humana em geral".

Constituem também outros aspectos da responsabilidade diacrônica (realidade em várias ordens jurídicas hoje), os seguintes pontos. Uma deslocação da função reativo-punitiva da responsabilidadeimputabilidade para outra de caráter solidário-preventiva. Aquela responsabilidade tinha uma "conotação repressiva: 'O que fizeste do teu irmão?', de traços regressivos (voltado para um horizonte passado, em puro raciocínio retroativo) e negativos, scilicet, de um juízo retroativo (ação no passado) culpabilizante (falta subjetivaculpa) e repressivo. ${ }^{64} \mathrm{Já}$ a responsabilidade-projeto de Ricoeur volta-se para o futuro, tendo um caráter proativo busca "definir o círculo das pessoas solidariamente investidas de novas missões" - , objetivo - descarta-se a busca por pessoas culpadas, para uma imputabilidade pelo "risco criado num horizonte futuro indeterminado" (OST, 1995a, pp. 308-309) - e preventivo. Portanto, essa responsabilidade é de natureza objetiva (seja por danos ou riscos, os quais podem alcançar as gerações futuras ${ }^{65}$ e coletiva ou solidária. ${ }^{66}$

Apresentadas as circunstâncias e os contornos gerais dessa responsabilidade diacrônica, seguem na próxima seção algumas considerações sobre os seus limites, em especial, na franja normativa do direito penal (ambiental).

\section{AS RACIONALIDADES JURÍDICO-AMBIENTAL E JURÍDICO-PENAL NA CONFIGURAÇÃO DO DIREITO PENAL AMBIENTAL}

Diante desses complexos problemas, o Estado e o Direito passam a ser constantemente estimulados a responder às incertezas científicas, ${ }^{67}$ aos danos ambientais futuros e aos riscos de alta consequência. Nesta árdua missão, o Direito Penal também é invocado a contribuir, lançando um olhar sobre as ameaças ao futuro, de modo a não se legar às diferentes expectativas de vida, as gerações futuras, um Planeta em condições de não existência, $\mathrm{o}$

\footnotetext{
${ }^{64}$ Neste sentido, e com peculiaridades muito semelhantes às supracitadas, Heller (2010, p. 27) menciona a "responsabilidade retroativa", scilicet, aquela "por atos que executamos".

${ }^{65}$ Sobre isso cfr.: OST, 1995a, pp. 305, 338 e 343; OST, 1995b, pp. 284, 287, 288, 300, 306, 307, 308.

${ }^{66}$ Sobre isso cfr.: OST, 1995a, pp. 307, 308, 310, 346, 355; OST, 1995b, pp. 310, 311; e VISSER'T HOOFT, 1991, pp. 37 e 46.

${ }^{67}$ Destaque para o abalo sofrido pela Ciência com as descobertas da Física Quântica, permitindo a formulação do princípio da indeterminação ou da incerteza, cfr. HEISENBERG, 1987. Incerteza que acaba despertando, no campo jurídico-ambiental, e,
} 
que levaria a temer pelos nossos filhos e netos porvindouros (STRATENWERTH, 1993, p. 680). Chega-se assim à intrigante proposta (ao menos, em termos precisos e diretos) desse autor de "salvaguarda do futuro com os meios do Direito Penal". Tal pensamento inicia um amplo debate sobre a tarefa do Direito Penal quanto ao asseguramento do futuro diante do contexto da sociedade de risco. Considerando-se que os problemas socioambientais, em grande parte, decorrem do avanço do progresso tecnológico, esse penalista adverte sobre a necessidade de uma expansão do âmbito de atuação do Direito Penal, propondo uma extensão da função de proteção de bens jurídicos, de modo que esta absorva a tutela das condições indispensáveis de sobrevivência das gerações futuras.

É crível a tensão identitária enfrentada pela tenra franja normativa do Direito Penal Ambiental, posto que, de um lado, não pode ela se imunizar contra os novos problemas que reclamam a sua intervenção (não sendo aconselhável esquivar-se de atuar em alguns deles, jamais em todos); e, de outro, ela precisa conservar sua estrutura, ainda que mínima, sob pena de total descrédito social e de significação. Perante o sério obstáculo de conformação dogmática pelo qual passa o Direito Penal Ambiental, bem como o despontar do Direito Ambiental - com seus inovadores princípios, teorias e formas de tutela dos bens ambientais -, entreve-se uma perigosa influência do segundo sobre o primeiro. ${ }^{68}$ No intuito indispensável de se tutelar o meio ambiente, e, devido a sua precoce idade e maturidade como dogmática jurídica, o Direito Ambiental acaba, em alguns momentos, por irromper na racionalidade jurídico-penal, provocando algumas tensões de difícil, senão de impossível, solubilidade.

Esta "preocupação" é absolutamente justificável em face da expansão de mecanismos de tutela do meio ambiente, destacadamente pela seara criminal, cuja dogmática ainda patina entre posturas de duvidosa validade jurídico-penal, sobretudo na (in) viabilidade da tutela das gerações vindouras por meio do Direito Penal (Ambiental), bem como em relação a outras questões de legitimação e estruturação desse noviço segmento. Será, portanto, neste meandro de intersecções entre tais racionalidades jurídicas (a saber, ambiental e penal), ligadas por um objeto comum (a proteção dos bens ambientais para as gerações futuras), que circundam algumas notas sobre a (in) compatibilidade entre algumas propostas jurídico-penais ${ }^{69}$ relacionadas com a proteção das gerações

posteriormente, no jurídico-penal, o princípio da precaução, embora, no último, de uma maneira um tanto quanto polêmica, conforme análise a seguir desenvolvida.

${ }^{68}$ Segundo D’Ávila (2010, p. 16), o Direito Penal Ambiental, “(...) convertido em amplo campo de prova do que pode vir a ser o direito penal nos anos que seguem, muito tem a contribuir para a feição, ainda demasiadamente frágil, do direito penal que se deseja para este novo milênio”. Perigosa influência que não escapou à percepção de Greco (2006, p. 192), ao falar de “(...) um erro comum na argumentação dos estudiosos de direito ambiental, que consiste em ignorar os princípios de garantia e imputação do direito penal”. No contexto alemão, no direito penal ambiental, “(...) 'o núcleo do direito penal, orientado para a vítima e para o bem jurídico', foi relativizado por meio tão somente da adição do direito penal à política ambiental” (HASSEMER apud PRITTWITZ, 2016, p. 15, destaques do autor).

${ }^{69}$ Com destaque para as propostas dos tipos penais referidos ao futuro („zukunftsbezogenen Straftatbestände“) e dos delitos de comportamento por Stratenwerth (1993); dos delitos de acumulação por Kuhlen (1986 e 1993) e da expansão do princípio da 


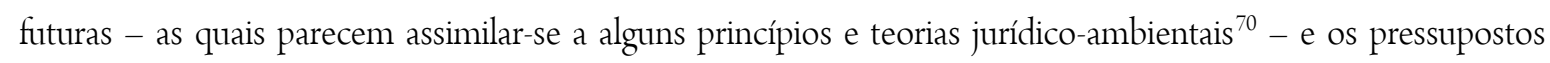
mínimos de validade jurídico-penal. ${ }^{71} \mathrm{O}$ problema que se coloca é: a proteção dos bens ambientais, no interesse das gerações futuras, seria compatível com os elementos mínimos de legitimação material do Direito Penal? Frente a tal problemática, parece possível traçar dois paradigmas bem definidos de proteção dos bens ambientais na contemporaneidade, o que, em virtude do intercâmbio entre as racionalidades jurídicas ambiental e penal, possibilita o surgimento de algumas propostas de duvidosa legitimidade nesse último âmbito normativo.

O primeiro dos paradigmas caracteriza-se pelos princípios de cariz iluminista, no qual a responsabilidade penal possui um efeito reativo sobre condutas (no mínimo culposas) praticadas no passado. Aqui a pena tem como meta retribuir a indiferença manifestada pelo delinquente sobre a relação ontoantropológica de cuidado-deperigo para com os outros seres-aí comunitários. ${ }^{72}$ Assim, a imputação do delito atua de forma regressiva sobre um post factum determinado, na medida em que desvalora jurídico-penalmente condutas ofensivas aos bens jurídico-penais, ou seja, ofensas de três diferentes níveis, a saber: o dano/violação, o concreto pôr-em-perigo e o cuidado-de-perigo, todas elas compactuando do fio condutor da "perversão da matricial e originária relação de cuidado-de-perigo" (FARIA COSTA, 2000, p. 634). Em síntese, os contornos desse Direito Penal moderno são: (i) a responsabilidade subjetiva e a imputação individual; (ii) a indispensável determinação da relação de causalidade (em regra, de natureza simples, como uma causa-efeito); (iii) o marco histórico da sociedade industrial; (iv) a tipicidade penal constatada pela real ofensa causada aos bens jurídico-penais; (v) a legalidade estrita; (vi) a função repressiva do direito.

O segundo deles surge das ideias tardo-modernas, no qual as diferenças substanciais em relação aos pressupostos de legitimidade e da intensidade das sanções jurídicas parecem sucumbir em prol da superestimação da proteção das gerações futuras. A forma reativa das diferentes responsabilidades jurídicas da modernidade perde força e se inicia a construção e o aperfeiçoamento de uma responsabilização (pseudo) penal proativa, atuando sobre condutas futuras (FARIA COSTA, 2009, pp. 50-51). A pena assume-se como mero efeito do

precaução para a seara jurídico-penal, denominada aqui como Direito Penal de Precaução (tema abordado por Mendoza Buergo, Casabona, Sola Reche e Schroeder). A título de menção, Roxin (2006, pp. 29-31; 2007, p. 456) parece admitir, ao menos em parte, que a proteção de embriões humanos, a tutela dos animais contra maus-tratos, a evitação da extinção de espécies (de animais e de plantas) e da destruição do clima, bem como a tutela das condições de existência das gerações futuras devem ser objeto de tutela pelo direito penal. Para mais detalhes, cfr. a nota 73 abaixo e o corpo do texto a seguir.

${ }^{70}$ Com destaque para os princípios jurídico-ambientais da equidade intergeracional e da precaução. A saber, as teorias da imputação por cúpula ou da “cúpula invisível („unsichtbare Cupola“)” de Teubner (2005) e da “responsabilidade-projeto” de Ost (1995a). Ambas compartilham de mecanismos de imputação coletiva; dispensam, flexibilizam ou presumem nexos de causalidade; e implicam uma sanção (de natureza civil) coletiva, fundada na responsabilidade coletiva ou solidária.

${ }^{71}$ Destacando-se a teoria da proteção de bens jurídicos, a responsabilidade subjetiva, a forma unificadora dos desvalores da ação e do resultado, e por fim, a ofensividade, cfr.: CAETANO, 2016, pp. 170-186, 205-213, 392-401.

${ }^{72}$ Trata-se aqui da "posição neo-retributiva de fundamento onto-antropológico" de Faria Costa (2005, p. 208) que tem na retribuição a manifestação mais autêntica das ideias fortes e fulcrais de responsabilidade e igualdade material do ser comunitário. 
descumprimento da norma penal para corrigir disfunções sociais. ${ }^{73} \mathrm{~A}$ imputação do delito passa, absurdamente, a presumir, ou a dispensar, a constatação do nexo de causalidade - efeito comum aos delitos de acumulação e ao Direito Penal de Precaução. ${ }^{74}$ A ofensa reduz-se ao mero descumprimento da norma (conforme os modelos dos crimes de acumulação, de infração de dever e de comportamento). Em síntese, os contornos desse modelo "panpenal" (FARIA COSTA, 2009) são: (i) a responsabilização objetivo-solidária e a imputação coletiva; (ii) a indeterminação e, logo, a presunção ou dispensa da prova de causalidade (marcada por uma causalidade complexa, influenciada por condutas de terceiros não identificáveis, efeitos somativos, aditivos e sinérgicos, fatores acidentais inerentes ao próprio meio ambiente, além de problemas de ordem geográfica e temporal entre a prática dos fatos e os resultados); $;^{75}$ (iii) o marco histórico da sociedade de risco; ${ }^{76}$ (iv) a tipicidade penal afirmada pela mera criação, ou pelo incremento ilícito, de riscos ao meio ambiente e à saúde humana, independentemente da real ofensa provocada aos bens jurídico-penais; ${ }^{77}$ (v) a legalidade (mitigada ou ampla) passa a absorver conceitos

\footnotetext{
${ }^{73}$ Destacam-se aqui os traços gerais das concepções exacerbadamente formais de crime, recentemente fundadas sob o pensamento funcionalista e, portanto, voltadas para as consequências da regulação normativa: a pena. Neste macromodelo (com inúmeras nuances) não há limites entre o relevante e o irrelevante penal, o que passa a ser problemático por não fomentar quaisquer mecanismos de orientação do dever ser do Direito Penal, equiparando este e o seu ser, logo crime é o que a norma diz ser (delito = violação de dever) e nada mais. Em suma: o dever jurídico-penal se fundamenta de modo exclusivamente jurídico-legal. Citam-se, a título demonstrativo, três teorias exemplificativas dessa extremada configuração formal de delito: (i) a mais divulgada é o funcionalismo sistêmico-penal de Jakobs. Este vê a pena como restauração da quebra de vigência da norma, o crime reduz-se à negação da norma penal vigente (o seu descumprimento) e a função do Direito Penal é a manutenção da norma (expectativa normativa); a segunda teoria, representada por Freund (2009, p. VII), destaca que "os pressupostos de um delito são funcionalmente determinados tendo em vista a questão das consequências jurídicas existentes”; e a última se encontra em Lesch (2001), que fulmina as diferenças entre o injusto, a culpa e o delito (p. 29 e 32), chegando a sustentar a culpabilidade (= injusto) como a "realização errônea da vontade" (p. 31) que sempre será fundada no fato reconhecido como perturbação social, devendo ser compensada com a pena (p. 30).

${ }^{74}$ Intui-se que os delitos de acumulação, em razão do alargamento da relação conduta-bem jurídico, outra coisa não fazem, senão presumirem inúmeras relações de causalidade entre as condutas massivas ínfimas e o dano ambiental futuro. Considerando-se que a presunção de causalidade é uma manifestação do princípio jurídico-ambiental da precaução, deduz-se que eles estão intimamente ligados à tutela das gerações futuras através da influência deste princípio no Direito Penal. Tanto que Schroeder (2004, p. 424) reconhece nele tanto uma pretensão de proibir condutas em que o nexo causal com os danos futuros ainda não é comprovado cientificamente, quanto de "(...) proibir ações que podem causar danos graves não por si mesmas, mas se forem levadas a cabo de uma forma cumulativa”. Não por acaso, atribui-se à proposta de Kuhlen (1986 e 1993) sérias violações dos princípios da culpabilidade (por ensejar uma responsabilidade por fatos de terceiros, e, portanto, uma sanção ex iniuria tertii), da igualdade, da ofensividade, da presunção de inocência e do in dubio pro reo, da personalidade e proporcionalidade das penas. Cfr. outros apontamentos nesse sentido, a seguir, em continuação ao texto principal, para onde remetemos o leitor.

${ }^{75}$ Neste sentido, por todos, cfr.: BECK, 2006, p. 228; D’AVILA, 2005, p. 385; FARIA COSTA, 2009, p. 54; WALING, 1991, p. 215; WITTECK, 2004, pp. 19-23.

${ }^{76}$ Neste sentido, por todos, cfr.: KUHLEN, 1993, p. 699; MENDOZA BUERGO, 2001, pp. 23-24, 34-41; PRITTWITZ, 2004, p. 149-152; SILVA DIAS, 2003, p. 311; SILVA DIAS, 2008, p. 36; STRATENWERTH, 1993, p. 681; WITTECK, 2004, pp. $19-23$.

${ }^{77}$ Eis aqui a tipicidade exclusivamente formal, constituída para combater macroproblemas sociais de natureza estatística, derivados, em regra, de hipotéticas generalizações de ações em determinado setor, como as infrações de trânsito, as microcontaminações do meio ambiente, as contribuições tributárias e o porte e consumo de quantidades ínfimas de tóxicos. Especial destaque ganham aqui as propostas de delitos de acumulação, nos quais "o desvalor fundamental do contributo singular não é descritível em termos de ofensividade, mas apenas em termos de disfuncionalidade” (SILVA DIAS, 2003, p. 320). Em virtude do deslocamento, em termos de ofensividade, provocado pelos crimes de comportamento, de dever e fundados no princípio de precaução, orientando-se pela mera disfuncionalidade social também parecem passíveis de críticas semelhantes. Prittwitz (1993, p. 366) denunciou também que
} 
estranhos ao Direito através das normas técnicas; ${ }^{78}$ (vi) a função preventiva do Direito. ${ }^{79}$

Para ilustrarmos o perigo dessa migração da racionalidade jurídico-ambiental para o campo penal, inicialmente estabeleceremos um paralelo entre a teoria da imputação por cúpula de Teubner e os delitos de acumulação. A primeira consiste em uma responsabilização coletiva por danos ao ambiente decorrente da superação do pesadelo dos juristas neste campo: a crise da imputação de causalidade (TEUBNER, 2005, p. 191). ${ }^{80}$ A imputação por cúpula de Teubner (2005, p. 191) suprime o estabelecimento do nexo de causalidade, da prova individual de causalidade, "(...) substituindo imputação causal por imputação coletiva. Sob o teto da cúpula, a responsabilidade individual transforma-se em responsabilidade coletiva”. Segundo Teubner (2005, p. 201), não se deve procurar os agentes individuais culpados, pois não é possível “(...) optar entre responsabilidade coletiva ou individual, mas entre responsabilidade coletiva ou nenhuma responsabilidade, uma vez que sem o nexo causal não há responsabilidade individual".

A proposta dos delitos de acumulação foi impulsionada pelos constantes despejos de lixo doméstico no Rio Reno, por isso sua origem confunde-se com a engenhosa justificação típica do $\$ 324$ StGB pelas mãos de Kuhlen (1986 e 1993). A assunção das ideias de que consideráveis danos ambientais decorrem de contaminações não significativas ligadas a um grande número de ações isoladas, e, de que as esferas civil e administrativa são insuficientes para impedi-las, conduziu ao reconhecimento de que era “(...) preciso afrouxar a relação penal préestabelecida entre e ação e o bem jurídico, uma vez que a ligação da responsabilidade penal na ação isolada é insubstituível” (KUHLEN, 1993, p. 698). ${ }^{81}$ Frente isso, Kuhlen (1986, p. 398) propôs classificá-lo como um tipo de acumulação, o qual “(...) não exige que uma ação individual cause um dano ou perigo, senão apenas que a ação individual faça parte de uma espécie de condutas, a qual, caso fosse realizada em grande número, causaria um dano

o incremento do risco proveniente de "perigos acumulativos", por meio dos delitos de acumulação, acabaria por afirmar progressivamente a identidade de "proibições de perigo e de lesão", bem como de "dolos de perigo e de lesão".

${ }^{78}$ Destaque aqui para as normas penais em branco e a acessoriedade administrativa do Direito Penal (gênero), principalmente em sua modalidade formal ou relativa ao ato administrativo (espécie), responsável por expor a invariável tensão do discricionário pertinente ao Direito Administrativo com o estritamente legal e taxativo do Direito Penal. Abundam-se nesse modelo os denominados crimes de mera desobediência, o que, além de acarretar uma verdadeira confusão entre os ilícitos administrativo e penal, transforma o juízo de tipicidade penal em mera análise do descumprimento das regulamentações administrativas. Conforme destaca Rodrigues (1996, p. 22), "a desobediência a estas prescrições constituirá, justamente, a ilicitude típica dos crimes ecológicos".

${ }^{79}$ Nas palavras de Faria Costa (2009, p. 50, destaques do autor), “(...) um direito penal que quer ser, por sobre tudo, preventivo, falando-se já mesmo em uma dimensão para-penal do próprio direito penal, ou defensor de um tempo futuro longínquo, defensor das gerações futuras". Também nesse sentido, cfr.: MENDES, 2000, p. 39 e WITTECK, 2004, pp. 20-21.

${ }^{80}$ A saber, o jurista alemão atribui três causas para tal crise: (i) o chamado efeito borboleta, no qual pequenas mudanças tecnológicas acumulam-se de forma lenta, podendo causar alterações drásticas abruptamente; (ii) os problemas de interferência de inovações tecnológicas; (iii) as coincidências causais improváveis, quando duas ou mais correntes causais venham a se unir imprevisivelmente.

${ }^{81}$ Este raciocínio decorreu tanto da "crescente dificuldade de produção jurídico-penal", evidenciada pelo "cada vez mais solto enlace entre a ação e o bem jurídico protegido” (KUHLEN, 1986, p. 395), não se encaixando o \$324 StGB em nenhum dos modelos de delito tradicionais (delitos de lesão, de perigo concreto e de perigo abstrato), quanto do reconhecimento de que todos esses são de ação individual (a ação individual constitui a base das formas de delitos conhecidas). 
ou perigo". Sabendo-se que cada ação individual de despejo de lixo é não-perigosa como regra, Kuhlen (1986, p. 400) adverte que "se tais despejos foram realizados em grande número, surge um perigo ecológico", portanto a particularidade dos tipos de acumulação, como o $\$ 324$ StGB, está nas ações individuais sequer consideradas abstratamente perigosas.

Trata-se de uma proposta de justificação típica na qual não seria exigida nem a lesão do, nem o perigo abstrato para com, o bem jurídico protegido (KUHLEN, 1986, p. 389), mas fundamentada em um juízo realista das ações praticadas por um grande número de indivíduos, descrita nos seguintes termos:

Por isso tem sido proposto identificar a poluição das águas como conjunto de casos cumulativos, o qual também abrange, por isso, ações inofensivas e singulares, pois sem uma proibição sancionatória de condutas desse tipo seria necessário considerar que elas seriam feitas em grande número e teriam como consequência uma perturbação das protegidas funções das águas (KUHLEN, 1993, pp. 714-715). ${ }^{82}$

São justamente os aspectos da autoria e do nexo de causalidade dessa proposta que apresentam os maiores déficits de legitimação material. Quanto ao primeiro, nota-se uma mudança de foco da pessoa individual para uma coletividade (ações coletivas enquanto praticadas por uma difusa gama de indivíduos sem prévio ajustamento entre os autores), por isso uma ofensa penalmente relevante ao bem jurídico-penal - apenas se globalmente considerada - depende de várias intervenções insignificantes de outros agentes. Quanto ao nexo causal, esse sofre uma dilatação significativa pelo alargamento máximo da relação "conduta - bem jurídico", porque, diferentemente dos delitos de perigo abstrato, dispensa-se a geral perigosidade da conduta para com o bem jurídico protegido em uma prognose ex ante.

Esses problemas levam inexoravelmente a uma imputação coletiva, já que os delitos de acumulação constituem uma técnica voltada para o enfrentamento de ações praticadas em massa, cuja lógica se pauta pela hipotética repetição de condutas sem ofensividade ao bem jurídico-penal. O nexo causal entre cada contribuição poluidora e o dano provocado (fruto da acumulação das ínfimas ações executadas em massa), i.e., na poluição punível, é presumido de forma tal que resta impossível estabelecer os reais efeitos e a participação contributiva exata ao dano de cada uma daquelas ações individuais. Por isso a crítica de que "(...) os tipos cumulativos não requerem, por isso, qualquer comprovação de causalidade (e de imputação objetiva) entre o contributo singular e o dano global" (SILVADIAS, 2003, p. 307).

Portanto, os delitos de acumulação - ao se regerem por uma lógica de responsabilidade coletiva e objetiva (em razão da mitigação e até da supressão das relações de causalidade altamente complexas) - não podem ser aceitos pelo ordenamento jurídico por subverterem as pilastras básicas do que se conhece por Direito Penal: a responsabilidade individual (a imprescindibilidade do nexo causal) e subjetiva (a culpabilidade), bem

\footnotetext{
${ }^{82}$ Tanto que o exemplo mencionado por Kuhlen (1993, p. 712) é o de que seria: “(..) delituoso e será possivelmente punido de fato, se alguém despeja seu esgoto doméstico dentro de um grande e já considerável rio poluído, embora não seja evidente, qual impacto prejudicial este despejo poderia ter".
} 
como a ofensa a bem jurídico. Prittwitz (1993, p. 371) adverte que a evolução dos delitos de lesão aos de perigo concreto, e, depois, dos de perigo abstrato até aos delitos de risco e de acumulação, fez com que os problemas da causalidade e da imputação individual se tornassem irrelevantes.

Dentro da "solidariedade no pool de risco" da imputação por cúpula, a "(...) responsabilidade coletiva significa responsabilizar agentes individuais por atos que foram cometidos por terceiros" (TEUBNER, 2005, p. 211). Esse aspecto é uma das principais críticas formuladas aos delitos de acumulação, o que equivale à violação do princípio jurídico-penal da culpabilidade, pois permite que se impute "(...) ao autor de um dano cumulativo contribuições alheias ao fato, algo que, evidentemente, segundo a dogmática da participação não se aceita nos casos normais" (MÜLLER-TUCKFELD, 2000, p. 513). Não se pode responsabilizar cada indivíduo por fatos (injustos acumulativos) realizados por todos os outros, ${ }^{83}$ isso seria " ( . . ) fundamentar a pena ex iniuria tertii, que é precisamente o que proíbe o princípio da culpabilidade" (RODRIGUEZ MOURULLO, 2005, p. 176). Freeland (2001, pp. 258-259), ao comentar as diferenças entre as responsabilidades civil e penal por danos ambientais, deixa bem claro que, na última, “(...) não existe a mera responsabilidade pelo resultado (responsabilidade objetiva); a responsabilidade penal se funda no dolo ou na culpa do autor".

Garcia-Pablos de Molina (2006, p. 220) adverte que o dano acumulativo é um traço comum do direito administrativo (sancionador), constituindo-se em uma ideia que prescinde da valoração do fato concreto, considerado isoladamente, e acaba por atuar na avaliação do "perigo global", scilicet, com o trato de perigos estatísticos derivados da hipotética generalização de ações em determinado setor. Sendo este o modus operandi dos delitos de acumulação, tal raciocínio não se coadunaria com a racionalidade jurídico-penal, pois esta “( ... ) só pode responsabilizar o sujeito determinado pelo concreto significado da conduta isolada que realizou: o direito penal clásico não suportará uma imputação 'ex iniuria tertii'. A presunção de perigo intentada nesta forma de criminalização acaba por responsabilizar alguém por um perigo irreal, inexistente, "baseado tão só na hipótese de que outros se comportarão no futuro de forma incorreta (reage-se com uma pena porque se todo mundo fizesse o mesmo...)" (FEIJOO SANCHEZ, 2011, p. 45)..$^{84}$

A solidariedade na responsabilidade civil objetiva por danos ambientais não pode ter ressonância alguma na esfera penal, sob pena de implodir toda a racionalidade jurídico-penal duramente constituída na modernidade,

\footnotetext{
${ }^{83}$ Proposta esta inadmissível no campo penal, pois “ ( ... o processo de imputação deve ter como ponto de gravidade a consideração de que só será possível atribuir-se o injusto a alguém quando sua realização possa ser afirmada como obra sua e não de terceiros" (TAVARES, 2002, p. 252).

${ }^{84} \mathrm{Ou}$ ainda, nas palavras de Mendoza Buergo (2010, s.p.), ao nível da tipificação penal, o fato considerado como crime foge absolutamente ao controle de cada indivíduo considerado isoladamente, já que apenas será possível falar em crime se outras pessoas também praticarem determinadas condutas, as quais se somarão as outras perpetradas em grande número. Seria assim imputado ao autor a prática de um injusto penal, no qual tão só contribuiu com (no máximo) um risco para o bem jurídico tutelado, e isso, caso se considerem as várias ações praticadas por “(...) outros eventuais e indeterminados autores que, por sua vez, são responsáveis por um risco que unicamente existe em função da repetição de condutas alheias”.
} 
e isso é justamente o que implica o delito de acumulação. Portanto, esses no Direito Penal Ambiental e o princípio da precaução no Direito Ambiental têm um centro gravitacional comum: todos, em suas respectivas searas (penal e ambiental), buscam suprir tanto os problemas de estabelecimento do nexo de causalidade, quanto os de imputação de condutas massificadas. Os primeiros enfrentam a impossível compatibilização da imputação de condutas massificadas com a exigência restrita de individualização e de responsabilização subjetiva do Direito Penal, demonstrando a sua clara inviabilidade.

Outro ponto questionável é a migração do princípio da precaução para o Direito Penal Ambiental, a qual se dá (não só) por intermédio dos delitos de acumulação. A imputação nos delitos de acumulação torna-se possível apenas com o relaxamento da relação entre as ações individuais praticadas em massa e o bem jurídicopenal, o que implica a flexibilização (ou supressão) do nexo de causalidade. A precaução proíbe tanto condutas cujo nexo causal em relação a danos futuros não é passível de comprovação científica, quanto ações não lesivas "isoladamente", mas que, se praticadas de maneira "cumulativa", poderiam gerar danos graves (SCHROEDER, 2004, p. 424).

A precaução caracteriza-se pela máxima antecipação nas condutas dos indivíduos, fundamentada na incerteza científica envolvida e nas significativas ameaças de danos irreversíveis; assim, ela acaba por atingir uma preservação dos bens ambientais para as gerações futuras. Trata-se de uma responsabilidade proativa que dispensa, até mesmo, o nexo de causalidade entre o dano (ou o perigo dele) e a ação, não sendo demais lembrar que o problema da causalidade é tema comum (e problemático) às temáticas deste princípio e dos delitos acumulativos. Silva Dias (2008, p. 31) passa a classificar os últimos como "uma das modalidades dos delitos de risco", que refletem "o fundamento consequencialista e a lógica da ação coletiva, rectius, da soma de contributos individuais para o desencadeamento de grandes riscos"; sendo tal modalidade apresentada, em regra, "no quadro de uma função do Direito Penal de proteção das gerações futuras". O voltar de olhos da precaução para o futuro, coloca-o em direta conexão com a (o princípio da) equidade intergeracional, sendo os delitos de acumulação um dos seus reflexos no Direito Penal Ambiental. Esse modelo, conforme os moldes propostos por Kuhlen através de sua interpretação do $\$ 324 \mathrm{StGB}$, ao visar a preservação das condições naturais da vida, dá margem à legitimação dos tipos penais acumulativos que visam evitar riscos ambientais futuros (GUIRAO, 2002, p. 12).

O princípio da precaução poderia surgir também como critério substituto do (ou complementar ao) postulado do risco permitido na configuração típica dos delitos, tendo advertido Sola Reche (2004, p. 491) que a transposição desse princípio não se deu de forma expressa nas disposições penais, destacando que o sentimento de insegurança acabou por atrair o pêndulo penal em favor da excepcional (e apenas em alguns âmbitos do Direito Penal) substituição da perigosidade da conduta pela precaução. Mendoza Buergo (2005, p. 331) salienta que a justificação desse princípio, na seara penal, adviria do medo em relação às possíveis consequências, a médio e 
longo prazo, daquelas atividades ou condutas cujos efeitos não são conhecidos nem se podem controlar no estado da arte científica hodierna. A questão crucial nesta proposta gira em torno da flexibilização, ou não, de dois pressupostos presentes no modelo de responsabilização penal: o conhecimento e a previsibilidade firmados sob os nexos causais cientificamente estabelecidos. Chega essa autora à conclusão de que o princípio da precaução não tem o condão de justificar, e nem de proibir por meio de penas, a mera execução de atividades não comprovadamente inofensivas para o homem e o meio ambiente, advertindo “(...) que será decisiva a infração da proibição ou das medidas precaucionais aconselhadas por aquele princípio, estabelecidas preferencialmente na ordem administrativa (...)" (MENDOZA BUERGO, 2005, p. 331).

O afloramento da precaução dar-se-ia pelas ordens administrativas, que são, por excelência, o habitat daquele princípio, conforme supramencionado; podendo ela ser absorvida pela malha penal através dos tipos penais de mera desodebiência, vinculados a alguma das modalidades de acessoriedade administrativa (e, aqui, não necesariamente sob a veste acumulativa). Nesse âmbito, nota-se um vínculo problemático entre alguns crimes da Lei Federal n. ${ }^{0}$ 9.605/98 - suscetíveis de uma interpretação como delitos de acumulação - e a acessoriedade administrativa de que são portadores, consistindo na insuficiência dos atos administrativos gerais em definir, com precisão, a quota individual de poluição ou de utilização dos bens ambientais, nomeadamente os artigos 29,34, 39, 45 e 54 . Nesses tipos resta dificultada ou, até mesmo, impossibilitada a determinação da "medida da participação criminosa de cada sujeito ativo quando se está diante dos delitos cumulativos" (DOMINGUES, 2009, p. 60), o que leva a um dilema: ou se pune todos os envolvidos de forma igualitária, atropelando as diversificadas formas de participação no dano acumulativo (violando os princípios da culpabilidade, da individualização das penas e da responsabilidade subjetiva); ou se ignora o dano acumulativo sob o véu da legalidade administrativa através das permissões, autorizações e licenças ambientais (DOMINGUES, 2009, p. 60).

Steindorf (1997, p. 47) aponta, de maneira semelhante, os casos de autorizações administrativas apreciadas isoladamente que permitem insignificantes e social-adequados prejuízos ao meio ambiente, os quais, segundo efeitos somativos, aditivos e sinérgicos causariam danos ao bem jurídico-penal ambiental. Ele complementa que tais danos, mesmo envolvidos por comportamentos individuais, não tornam favorável esta compreensão do injusto acumulativo, pois os efeitos somativos e acumulativos não são reconduzíveis aos comportamentos legais e ilegais em repetição, além de dependerem do direito local (i.e., leis estaduais e/ou leis municipais). O autor ainda destaca conclusivamente que se trata de um "real dilema do direito penal ambiental" (STEINDORF, 1997, p. 47). Observa-se nesses casos que, se uma ação for efetuada sem a devida autorização da Administração ou em desconformidade com a legislação vigente (de natureza não criminal), será prescrita uma pena "sem que tenha se produzido um dano ou dado lugar a um perigo concreto" (SCHROEDER, 2004, p. 429). O bem jurídico-penal nesta forma de incriminação é tão somente a obediência para com Administração 
(SCHROEDER, 2004, p. 429) (ou para com a ordem jurídica), cujo exemplo é o artigo 330, d, 5, StGB, ${ }^{85}$ que considera como inexistente qualquer autorização obtida por ameaça, suborno, coação ou derivada de uma informação falsa ou incompleta.

Segundo Schroeder (2004, p. 429), isso faria com que as ações "autorizadas" nesses casos duvidosos sejam consideradas criminosas e por isso constituiria "uma importante contribuição à realização efetiva do princípio da precaução". Tema conexo a este é a possibilidade de responsabilização penal dos encarregados públicos pela omissão de efetivas políticas de prevenção (SOLA RECHE, 2004, p. 491), o que leva Romeo Casabona (2004, p. 419) a defender a imputação do delito de prevaricação qualificada aos funcionários públicos negligentes, dificilmente abarcado pelo tipo genérico. ${ }^{86}$ Em que pese todo esse esforço hermenêutico de compatibilização da precaução no âmbito jurídico-penal, todas essas propostas mostram-se inaceitáveis perante uma ideia de injusto material por esvaziar significativamente o que se deve entender por delito em um Estado que se pretenda democrático e de direito.

Há também um enlace entre o princípio da precaução e os contornos do dever de cuidado, cuja infração é o fundamento da negligência (o delito culposo). Embora reconhecida a amplitude desse princípio, muitas vezes direcionado como orientação ao Poder Público para medidas políticas amplas, Mendoza Buergo (2005, p. 333) considera que alguns dos pontos relativos "à imprudência e à determinação do marco do risco permitido têm uma clara conexão com as que estão igualmente na base do princípio da precaução". Um exemplo seria a denominada culpa ou negligência por assunção, marcada pela "infração do dever objetivo de cuidado naqueles casos em que o sujeito coloca em prática ou assume a realização de uma ação sem os necessários conhecimentos para este" (MENDOZA BUERGO, 2004, p. 453).

Embora não consideremos dogmaticamente adequado, essa proposta seria passível de aplicação através da famigerada figura da "imperícia”, ainda presente no art. 18, II, in fine, do CP. Ainda, segundo Mendoza Buergo (2005, p. 334), “(...) a tradução plasmada no Direito Penal da máxima de comportamento ditada por uma versão extrema do princípio da precaução: 'na dúvida, abstenha' ou 'in dubio pro securitate'. Schroeder (2004, p. 427) destaca que este princípio desenvolveu-se a partir daquele outro postulado jurídico-ambiental da precaução, e, em

\footnotetext{
${ }^{85}$ Disponível em: <www.gesetze-im-internet.de/bundesrecht/stgb/gesamt.pdf>. Acesso em: 20. fev. 2013, tradução livre: "330d Definições - [...] uma ação sem autorização, permissão ou outra licença: também uma ação baseada em uma ameaça, corrupção ou obtida a autorização, permissão ou licença por conluio ou através de ilícitas ou defeituosas informações".

${ }^{86}$ Romeo Casabona (2004, p. 419) afirma que, embora a precaução não implique diretamente a responsabilidade penal, a sua vinculação às normas extrapenais (as quais, por sua vez, são vinculantes para os gestores de risco) fazem de sua inobservância no âmbito administrativo uma forma de prevaricação. Ou seja, incumbe ao funcionário público interpretar e aplicar as normas extrapenais, e, portanto, o descumprimento delas pode ensejar a consumação do delito de prevaricação qualificada (por violação do princípio da precaução), e cita o exemplo da autorização por parte da autoridade competente da liberação voluntária de organismos geneticamente modificados, a qual infringe dolosamente o prescrito a este respeito. Na legislação penal ambiental brasileira, há na seção V (Dos crimes contra a administração ambiental - artigos 66 a 69-A) da Lei 9.605/98 um rol de crimes que
} 
sentido semelhante à esta doutrina, há decisão que invoca o princípio do in dubio pro societate na tutela penal do meio ambiente, acolhendo a aplicação do princípio da precaução que, por sua vez, levaria ao rechaço do princípio da insignificância; nos seguintes moldes:

EMENTA: PENAL. PROCESSUAL. DENÚNCIA: ART. 34, DA LEI 9.605/98: PRÁTICA DE ATOS DE PESCA MEDIANTE PETRECHO PROIBIDO: DENÚNCIA REJEITADA: FUNDAMENTO: INOCORRÊNCIA DE PREJUÍZO À FAUNA AQUÁTICA. PEQUENA QUANTIDADE DE PEIXES CAPTURADOS: CONDUTA MATERIALMENTE ATÍPICA: PRINCÍPIO DA INSIGNIFICÂNCIA. INAPLICABILIDADE NA FASE DO RECEBIMENTO DA DENÚNCIA. EXORDIAL QUE PREENCHE TODOS OS REQUISITOS LEGAIS. DESCRIÇÃO DE CONDUTA TÍPICA. GARANTIA DO EXERCÍCIO DO DIREITO DE DEFESA. PREVALÊNCIA DO PRINCÍPIO IN DUBIO PRO SOCIETATE. INDÍCIOS SUFICIENTES DE AUTORIA E MATERIALIDADE DELITIVAS. JUSTA CAUSA PARA A INSTAURAÇÃO DA AÇÃO PENAL. RECURSO PROVIDO. 1 - Denúncia que imputou ao recorrido a prática do delito previsto no artigo 34, \$ único, da Lei 9605/98, complementada pela Portaria $n^{\circ} 30 / 2003$, do IBAMA, por praticar atos de pesca amadora em uma embarcação, mediante o uso de petrecho proibido rejeitada ao fundamento de falta de justa causa para a ação penal pela atipicidade da conduta, tendo em vista que a captura de apenas 50 peixes causou prejuízo insignificante à fauna aquática. 2 - O bem jurídico tutelado pela lei ambiental é elevado à categoria de bem essencial à vida e à saúde de todos. Vige, em sede de direito ambiental, o princípio da precaução no que se refere à degradação da qualidade ambiental. Pune-se não só as condutas que causam a efetiva lesão, mas também as que provocam riscos de potenciais lesões ao meio ambiente. 4 - A aplicação do princípio da insignificância é vinculado à possibilidade de mensuração do bem jurídico tutelado. Não há como aplicá lo em sede de crimes ambientais especialmente na fase de recebimento da denúncia. Aplicação do princípio do in dubio pro societate. 5 - Denúncia que descreve todos os elementos que possibilitam o recebimento e o exrcício da ampla defesa. Conduta tipificada no artigo 34, S único da Lei 9605/98.

6 - Provas da materialidade delitiva e indícios suficientes de autoria colhidos no inquérito policial.

8 - Recurso em sentido estrito provido, determinada de remessa dos autos à vara de origem, para o regular prosseguimento da ação penal. ${ }^{87}$

Trata-se de inquietante diagnóstico que perverte toda a racionalidade jurídico-penal, pois anula o princípio da insignificância, que não pode ser afastado do âmbito de aplicação do Direito Penal Ambiental. ${ }^{88} \mathrm{~A}$

trata de desvio de funções, de prevaricações dos funcionários públicos e do impedimento ou da obstrução de atividades administrativas relacionadas ao poder de polícia do Estado.

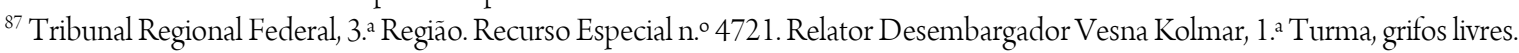

${ }^{88}$ Há decisões em sentido contrário a supracitada, a saber: "EMENTA: AGRAVO REGIMENTAL. RECURSO ORDINÁRIO EM HABEAS CORPUS. CRIME AMBIENTAL. AUSÊNCIA DE DANO AO MEIO AMBIENTE. CONDUTA DE MÍNIMA OFENSIVIDADE PARA O DIREITO PENAL. ATIPICIDADE MATERIAL. PRINCÍPIO DA INSIGNIFICÂNCIA. APLICAÇÃO. 1. Segundo a jurisprudência do Supremo Tribunal Federal, o princípio da insignificância tem como vetores a mínima ofensividade da conduta do agente, a nenhuma periculosidade social da ação, o reduzido grau de reprovabilidade do comportamento e a inexpressividade da lesão jurídica provocada. [...] 3. Agravo regimental improvido" (Superior Tribunal de

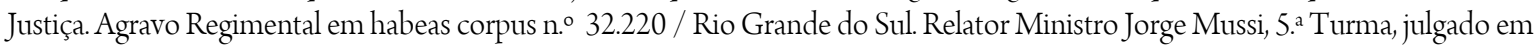
04.10.2012); "EMENTA: AGRAVO REGIMENTAL EM RECURSO ESPECIAL. CRIME CONTRA O MEIO AMBIENTE. ART. 34 DA LEI N. 9.605/1998. PESCA EM PERÍODO PROIBIDO. ATIPICIDADE MATERIAL. AUSÊNCIA DE EFETIVA LESÃO AO BEM PROTEGIDO PELA NORMA. IRRELEVÂNCIA PENAL DA CONDUTA. PRINCÍPIO DA INSIGNIFICÂNCIA. APLICAÇÃO. 1. Esta Corte Superior, em precedentes de ambas as Turmas que compõem a sua Terceira Seção, tem admitido a aplicação do princípio da insignificância quando demonstrada, a partir do exame do caso concreto, a ínfima 
tríade "bem jurídico-penal - princípio da ofensividade - princípio da insignificância" forma um núcleo duro da noção de injusto material, a qual se pensa conduzir ao mais correto e minimamente legítimo critério de incriminação. Adverte-se, porém, que são, no mínimo, discutíveis os pressupostos de aplicação do princípio da insignificância criados pela jurisprudência do STF, o que não pode ser aqui desenvolvido. Além disso, faz-se necessária uma cautela com o trato e a operacionalidade do próprio Direito Penal, não basta simplesmente invocar tout court a precaução para afastar aspectos indispensáveis desta ordem normativa (a saber, a insignificância e a ofensividade) e atribuir-lhe funções desmedidas de controle social de riscos em detrimento das garantias e dos direitos da pessoa humana. Neste sentido, segue a advertência de Canotilho (2006, p. 337):

(...) o risco legitimador dos princípios da precaução e da prevenção para a defesa do ambiente e dos direitos das gerações futuras não pode e não deve ser invocado para, seguindo a fenomenologia das labelling theories, combater a 'organizações de risco' quanto à segurança e defesa dos cidadãos.

Portanto, a recepção de todo o conteúdo precaucional pelo Direito Penal acarretaria em harmonizações nem sempre conciliáveis, v.g.: de um lado, as presunções de causalidade, a inversão do ônus da prova, a fundamentação em incertezas científicas, as hipóteses legais plásticas ou maleáveis, o in dubio pro natura ou pro securitae (precaução); e de outro, a causalidade determinada, a presunção de inocência e a ampla defesa, a fundamentação apenas na certeza científica, os tipos penais fechados e os abertos, mas determinados por lei, e, o in dubio pro reo.

A passagem de ações individualmente consideradas para ações coletivas conduz a uma crucial mudança

lesividade ao bem ambiental tutelado pela norma. Precedentes. 2. Muito embora a tutela penal ambiental objetive proteger bem jurídico de indiscutível valor social, sabido que toda intervenção estatal deverá ocorrer com estrita observância dos postulados fundamentais do Direito Penal, notadamente dos princípios da fragmentariedade e da intervenção mínima. 3. A aplicação do princípio da insignificância (ou a admissão da ocorrência de um crime de bagatela) reflete o entendimento de que o Direito Penal deve intervir somente nos casos em que a conduta ocasionar lesão jurídica de certa gravidade, permitindo a afirmação da atipicidade material nos casos de perturbações jurídicas mínimas ou leves, consideradas também em razão do grau de afetação da ordem social que ocasionem. 4. No caso, embora a conduta do apenado - pesca em período proibido - atenda tanto à tipicidade formal (pois constatada a subsunção do fato à norma incriminadora) quanto à subjetiva, na medida em que comprovado o dolo do agente, não há como reconhecer presente a tipicidade material, pois em seu poder foram apreendidos apenas seis peixes, devolvidos com vida ao seu habitat, conduta que não é suficiente para desestabilizar o ecossistema. 5. Agravo regimental a que se dá provimento a fim de acolher o recurso especial e absolver o agravante em face da atipicidade material da conduta praticada" (Superior Tribunal de Justiça, Agravo Regimental no Recurso Especial n. ${ }^{\circ} 1320020$ / Rio Grande do Sul. Relator Campos Marques, 5. ${ }^{a}$ Turma, julgado em 16.04.2013); "EMENTA: HABEAS CORPUS. IMPETRAÇÃO COMO SUCEDÂNEO RECURSAL. IMPROPRIEDADE DA VIA ELEITA. CRIME AMBIENTAL. PESCA MEDIANTE PETRECHOS NÃO PERMITIDOS. MÍNIMA OFENSIVIDADE AO BEM JURÍDICO TUTELADO. PRINCÍPIO DA INSIGNIFICÂNCIA. ATIPICIDADE MATERIAL DA CONDUTA. WRIT NÃO CONHECIDO. CONCEDIDA A ORDEM EX OFFICIO. 1. É imperiosa a necessidade de racionalização do emprego do habeas corpus, em prestígio ao âmbito de cognição da garantia constitucional, e, em louvor à lógica do sistema recursal. In casu, foi impetrada indevidamente a ordem contra acórdão de apelação, como se fosse um sucedâneo recursal. 2. Aplica-se o princípio da insignificância, reconhecendo a atipicidade material da conduta, consubstanciada em pescar mediante a utilização de petrechos não permitidos, se foi apreendida a ínfima quantidade de um quilo de peixe, o que denota ausência de ofensividade ao bem jurídico tutelado. 3. Flagrante ilegalidade reconhecida. 4. Habeas corpus não conhecido, mas concedida a ordem, ex officio, para trancar a Ação Penal no 996/2005, da Terceira Vara Criminal da comarca de Bauru/SP, cassando, por conseguinte, a sentença condenatória, decisão que fica estendida (art. 580 do Código de Processo 
no conceito material de delito: o desvalor do resultado decai da plataforma de aferição da imputação, restando relevância penal apenas a desconformidade legal da conduta, o que demonstra uma intenção precaucional. Há aqui um mero desvalor da ação consubstanciado no mero descumprimento da norma ou na ausência ou irregularidade da autorização administrativa, assumida a inofensividade de cada uma das condutas individuais, o que não pode ser aceito na concepção de injusto penal material. Portanto, essa expansão do princípio da precaução para o seio do Direito Penal e a tipificação por danos acumulativos não representam modelos legítimos de intervenção penal, porque se orientam pela lógica das sanções administrativas: “(..) não se trata de reagir a comportamentos que materialmente afetam ou perturbam outros âmbitos de organização, mas de prevenir situações nas quais isso pode chegar a suceder" (FEIJOO SANCHEZ, 2011, p. 49). Assim, no próximo tópico tentar-se-á formular um diagnóstico sobre a responsabilidade, a proteção das gerações futuras e o Direito Penal.

\section{UM DIAGNÓSTICO "PREOCUPADO" SOBRE A RESPONSABILIDADE, A PROTEÇÃO DAS GERAÇÕES FUTURAS E O DIREITO PENAL}

Embora tenha se chegado o momento de condensar o diagnóstico da moléstia sofrida pela responsabilidade - para alguns (WOLF apud STRATENWERTH, 1993, pp. 685-686), é ela uma consequência de sua própria senilidade -, antes nos incumbe uma rápida e fundamental reflexão: não há um milagroso remédio (não há cura!) para a doença em questão, e, por isso, as notas a seguir se aproximam de meros tratamentos (no máximo, meios de administração ou redução dos sintomas).

Considerando-se que a moléstia em questão é causada por multifatores (econômicos, políticos, jurídicos, éticos e sociais), consequentemente toda e qualquer resposta unidimensional constituirá um placebo, ${ }^{89} \mathrm{o}$ que, por outro lado, não impede o estabelecimento de prioridades segundo uma escala de gravidade dos sintomas (e principalmente de seus agentes causadores), bem como do desencadeamento de inter-relações entre eles..$^{90}$ Portanto, no sistema econômico está o principal mal a ser tratado, pois há um nítido quadro histórico de uma falência múltipla de órgãos provocada pelo economicismo capitalista (a exploração do homem pelo homem e a

\footnotetext{
Penal) ao corréu" (Superior Tribunal de Justiça, habeas corpus n.o 178208 / São Paulo. Relatora Ministra Maria Thereza de Assis

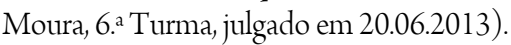

${ }^{89}$ A senilidade do "conceito de responsabilidade”, visto como uma “categoria antiquada”, encontra-se em: „Folg man den Auguren der Risikogesellschaft, so scheint nur das eine sicher zu sein: dass nämlich der, juristische Begriff der Verantwortung als ,altväterliche Kategorie ausgedient hätte" (WOLF apud STRATENWERTH, 1993, pp. 685-686).

${ }^{90}$ Advertimos que não será possível apontar (e justificar), nos restritos limites deste trabalho, todo um raciocínio escalonado e estratégico de qual, o porquê e do como determinado fator deverá ser tratado prioritariamente ou não em face dos demais, nem das razões de se combater um sintoma através do tratamento de outro. Contudo, um deles merecerá prioridade por constituir o verdadeiro calcanhar de Aquiles do problema, inclusive prevalecendo-se sobre os demais fatores.
} 
destruição desenfreada da natureza). ${ }^{91}$ E mais, segundo Prittwitz (2016, p. 21, destaque do autor), alguns fenômenos são "(...) declaradamente almejados (embriões), em parte como danos colaterais de extração de determinadas matérias-primas ou de métodos de produção (destruição da biodiversidade, exploração exaustiva dos recursos e lesão ao clima) predominantemente oriundos de atividades humanas legais".

Quanto ao inegável declínio da responsabilidade subjetiva em sede cível (e apenas aqui ela parece aceitável) por danos ou riscos ao meio ambiente, podemos esboçar algumas considerações. Primeiramente não negamos o avanço dado neste preciso âmbito, posto que interesses de toda uma comunidade (e, conforme o caso, de toda a humanidade) podem ficar à mingua da comprovação de culpa de um agente econômico, que extraí ganhos particulares de um patrimônio (natural-cultural) paradoxalmente de todos. Portanto, a responsabilidade separada da ideia de culpa é uma evolução inerente às relações diacrônicas entre as gerações, mas há possíveis armadilhas nesta seara. Castanheira Neves (2008, p. 79) reconhece a compatibilidade dos deveres de preservação do ambiente comunitário de existência com o primeiro nível da responsabilidade ("perante a humanidade"), mas adverte: "só que não de qualquer modo e sem limites".

Outra não é a "preocupação" de Kloepfer (2010, p. 51) para o caso da configuração de um dever comportamental compatível com o meio ambiente, mas que, por ser estruturado em termos muito genéricos, “(...) trataria o cidadão não mais primordialmente como uma pessoa que age autonomamente e sob sua própria responsabilidade, mas, em última análise, como objeto de uma ordem intervencionista de direito ambiental". O que, longe do razoável, inevitavelmente romperia com o princípio da autorresponsabilidade (responsabilidade pelas consequências da própria conduta), o que, em sede administrativo-sancionadora e criminal, tornar-se-ia a implosão do indispensável patrimônio liberal-iluminista da culpa, e, por isso, da própria dignidade da pessoa humana. ${ }^{92}$ Há, por fim, um elo inquebrável entre a liberdade e a responsabilidade, o qual possui um duplo efeito: o primeiro, de ordem geral, coloca a liberdade como pressuposto da responsabilidade, só é responsável a pessoa concreta e efetivamente livre; o segundo, de ordem especial, parte da ideia que “(...) essa ausência de testamento, a própria indeterminação da doação, preserva a liberdade do donatário. Sem essa liberdade, não haveria responsabilidade, com efeito", portanto a “(...) herança sem testamento', eis todo o tempo e a responsabilidade igualmente" (OST, 1999, p. 435).

Uma derradeira armadilha no campo da responsabilidade civil objetiva está em sua possível hipertrofia, o que leva Ost (1995b, p. 288) a advertir: “(...) o perigo é real”, pois a banalização da culpa em prol de mecanismos

\footnotetext{
${ }^{91}$ Nas palavras de Ost (1996, p. 203), o tratamento dado à natureza por um lado, e, aos grupos mais frágeis de outro, baseia-se em uma mesma lógica: "(...) a das extrações sem freio dos recursos de uma correspondente exploração dos outros (classes trabalhadoras outrora, países de terceiro mundo hoje)".

${ }^{92}$ No Direito Administrativo Sancionador e principalmente no Direito Penal valem as observações de Bim (2011, p. 829), de que "não se protege o bem jurídico sancionando quem não teve, ao menos, culpa", ou ainda de que "Defender o contrário é violar o
} 
automáticos de reparação pode efetivamente levar a desresponsabilizar os operadores econômicos. Isso seria possível em casos de criação de seguros ambientais financiados pelo Estado, rectius, por todos os cidadãos, o que dividiria os danos ao meio ambiente de forma desigual, ignorando seus verdadeiros responsáveis e as capacidades econômicas de responder por aqueles. Nesse diapasão, poderíamos acrescentar que o fardo (a responsabilidade nos moldes de Ricoeur) inexoravelmente passa pela autonomia e pelo comprometimento (a promessa) de cada pessoa, pois é justamente essa faculdade da promessa (a liberdade) que marca a pessoa como núcleo irradiador de responsabilidade (CASTANHEIRA NEVES, 2010b, p. 149; BRONZE, 2012, p. 185): ela promete responsabilizando-se e se responsabiliza prometendo. Portanto, trata-se de uma responsabilidade gerada pela promessa, a qual, por sua vez, pressupõe a liberdade: a capacidade de prometer da pessoa decorre de sua liberdade.

A promessa deve provocar no Direito uma abertura, já que se liga umbilicalmente à origem da responsabilidade, o que levou Nietzsche $(2008$, p. 47) a indagar, em relação à paradoxal tarefa de "educar e disciplinar um animal que pode fazer promessas": "Não é este o verdadeiro problema da humanidade?". É oportuno aqui relembrar com a raposa uma das tantas coisas esquecidas pelo homem: o cativar. Porque muitos dos sentidos atribuídos a esse termo expressam justamente vínculos humanos muito aproximados com a capacidade de prometer, como o se prender moralmente a alguém, ou ainda, o seduzir, o conquistar, o fascinar. Não surpreende que em todos eles a responsabilidade brote naturalmente como realidade correlata.

Essa capacidade de promessa, portanto de se responsabilizar, urge brotar na dimensão ético-prática das relações intersubjetivas, assumindo a forma de uma ética do cotidiano que não conheça fronteiras, raças, credos, Estados, orientações sexuais, espécies ou outras formas de separação ou divisão no tocante à vida (tão caras ao cogito moderno). Os placebos salvacionistas de infinitude dos recursos naturais devem ser suspensos, reconhecendo-se a própria finitude e ignorância da espécie humana, o que, por sinal, não nos torna menos responsáveis pelas condições de existência das gerações futuras, pelo contrário.

Eis aqui o diagnóstico completo da moléstia e o seu real enfermo: a amnésia culposa ou dolosa da humanidade. Além de todos os esquecimentos supramencionados sob o enredo do diálogo entre a raposa e o Pequeno Príncipe em torno da questão da responsabilidade, nunca é tarde para se relembrar, ao timbre de Ost (1999, p. 435), que, ao herdarmos o patrimônio natural-cultural, “(...) resta-nos transmitir esse dado para o reconstruir incessantemente - é essa a nossa responsabilidade". No âmbito ético-prático deverá se dar a cotidiana "preocupação" perante as gerações futuras, afastando-se, como nos adverte Ortega y Gasset (2004, p. 191), “(...) de renunciar à responsabilidade perante o próprio destino, dissolvendo-o entre a multidão". ${ }^{93}$

princípio da dignidade da pessoa humana, porque trata o homem apenas como meio para 'dar o exemplo', instrumentalizando-o, coisificando-o".

${ }^{93}$ Trata-se aqui do comportamento infelizmente da maioria das criaturas humanas, "a forma natural da vida é despreocupação", o "fazer o que faz toda a gente é a sua preocupação", portanto, "o eterno ideal do débil” (ORTEGA Y GASSET, 2004, p. 191). 
Entre o cruzar dos braços "despreocupadamente" e assumir "preocupadamente" a nossa responsabilidade-missão enquanto humanidade, ou entre o duelo entre Pilatos e Atlas, concluímos: somos responsáveis e o somos para além do Direito. Aliás, se atendidas às condições supramencionadas, sobretudo as de igualdade material de oportunidades, somos todos Atlas e nos cabe agir como tais nas relações intersubjetivas cotidianas. E, aqui, a normatividade jurídica tem um papel a cumprir, seja na seara administrativa, civil, penal, tributária ou em qualquer outra, ou seja, as gerações futuras serão protegidas indiretamente, pois os bens ambientais constituem objetos de proteção daquelas ordens jurídicas no interesse dos sujeitos de direito historicamente situados, as gerações presentes. Em termos jurídico-penais, alguns dos elementos do meio ambiente constituem bens jurídico-penais, cujos titulares são a coletividade de determinado Estado em determinado tempo. Em outros termos, indiscutivelmente mais diretos, façamos nossas as palavras de Prittwitz (2016, p. 22): “As vítimas de amanhã não tem lugar no discurso de legitimação do direito penal”.

Além desse comprometimento com Atlas, é imprescindível uma fisioterapia da memória humana para prevenir a moléstia apontada anteriormente, o que mais uma vez reaprenderemos com a raposa e o pequeno príncipe (SAINT ÉXUPÉRY, capítulo XXI, "A raposa", s.p.):

- Os homens esqueceram essa verdade, disse a raposa. Mas tu não a deves esquecer. Tu te
tornas eternamente responsável por aquilo que cativas. Tu és responsável pela rosa
[diríamos nós diacronicamente, tu és responsável pela humanidade presente e futura]...
- Eu sou responsável pela minha rosa [...pela minha e pela outra humanidade de nós e do vir-
a-ser-nós]... Repetiu o principezinho [...repete a humanidade], a fim de se [re] lembrar.

Delimitado o que resta ao Direito Penal Ambiental proteger (os bens jurídico-penais) e para quem proteger (para as gerações presentes), passa-se às conclusões deste trabalho.

\section{CONSIDERAÇÕES FINAIS}

Diante de todo o exposto, conclui-se de forma articulada e resumida que:

A histórica sonegação científica da natureza e das relações entre o homem e o meio ambiente (objeto de proteção do Direito Ambiental) explica, em parte, o fato de ser a dogmática jurídico-ambiental a franja mais dinâmica e também a mais frágil da Ciência Jurídica. É dinâmica na razão diretamente proporcional ao influxo de novos conhecimentos (provenientes da Biologia, da Ecologia, da Geografia, dentre outras tantas Ciências que se debruçam sobre o meio ambiente e as suas relações), bem como à necessidade de imposição de medidas eficazes de proteção e de melhoria das condições ambientais. É frágil porque, além de sua precoce existência enquanto

\footnotetext{
${ }^{94}$ Trecho em que Visser't Hooft (1991, p. 44), ao tratar do princípio da responsabilidade de Jonas, afirma: “(...) si nous nous croisons les bras, c'est à la limite tout futur qui va sombrer". O "despreocupadamente" (ver supra as notas 1 e 93) refere-se à formulação de Ortega y Gasset (2004, p. 191), que é implacável em sua crítica a "forma natural da vida": "São espíritos débeis que ao sentir o peso, ao mesmo tempo doloroso e deleitoso, de sua própria vida, se sentem assustados e então preocupam-se,
} 
dogmática jurídica, a dinamicidade de suas normas e teorias leva inevitavelmente a uma, no mínimo, difícil compatibilidade com as categorias jurídicas e as normas do ordenamento jurídico, principalmente com aquelas de natureza jurídico-penal.

O agravamento dos antigos - e, principalmente, o surgimento e o posterior incremento de recentes problemas ambientais levou a uma reformulação dos pressupostos tradicionais de imputabilidade e de responsabilidade nos planos ético e jurídico. No plano do Direito Ambiental destacam-se algumas propostas dinâmicas como as das responsabilidades objetiva e solidária, da imputação coletiva no Direito Civil (por exemplo, a "imputação por cúpula" de Teubner); da presunção ou até da dispensa da prova de causalidade no dano ambiental no Direito Processual Civil; da introdução de normas técnicas estranhas à racionalidade jurídica (e, destacadamente, de sua frequente revisão) no âmbito das normas jurídicas, o que refletirá na valoração da licitude/ilicitude das condutas praticadas, com destaque aqui para a acessoriedade administrativa do Direito Penal Ambiental e as resoluções e demais atos normativos no Direito Ambiental; da função preventiva e até mesmo precaucional.

Vislumbrou-se uma constante vinculação entre a "preocupação" com as futuras gerações e a proteção do meio ambiente, seja através dos provérbios de culturas populares, em razão dos desastres ambientais ocorridos no século XX, seja da ética do pós-guerra, seja do despertar do Direito Ambiental. Não se pode negar o pioneirismo desse ramo jurídico no tocante a responsabilidade pelas futuras gerações (rectius pelas condições de existência, não só, das gerações sucedâneas), a qual não é apenas jurídica, mas sobretudo e originariamente ética, vinculada que está, desde o início até o fim, com a "preocupação" com o outro (fundamento ontoantropológico de cuidadode-perigo de Faria Costa). Em virtude de todo o exposto, a responsabilização de pessoas hoje por atos lesivos ou atentatórios aos interesses (jamais direitos) das gerações futuras merece uma resposta jurídica, embora reconheçamos: fora da esfera do Direito Penal e com todas as cautelas imagináveis.

Notou-se uma perigosa ingerência de princípios e de teorias jurídico-ambientais (a saber, principalmente dos princípios da precaução e da equidade intergeracional, bem como da teoria da imputação por cúpula e da responsabilidade objetiva e coletiva) no Direito Penal Ambiental, manifestada nas flexibilizações da imputação individual, e, por conseguinte, da responsabilidade subjetiva; da exigência de determinação e de comprovação do nexo de causalidade nos crimes ambientais de natureza comissiva; da mitigação do princípio da legalidade estrita; e da constante ascensão da função preventiva (aproximando-se mesmo, em alguns casos, de uma função precaucional) e do declínio da função repressiva do Direito Penal. Esses traços foram notados sobretudo nos delitos de acumulação, no Direito Penal de Precaução e na "função" de proteção das gerações futuras pelo Direito

precisamente para tirar dos seus ombros o próprio peso que eles são, e lançá-lo sobre a coletividade; isto é, preocupam-se com despreocupar-se". 
Penal, o que comprovou a absoluta ruptura desses modelos para com os elementos mínimos de legitimação material do Direito Penal.

Notou-se que, tanto na seara penal, quanto na ambiental, ocorreu uma nítida tentativa de suprir os problemas do estabelecimento do nexo de causalidade e da imputação de condutas massificadas. Contudo, no âmbito jurídico-penal, tanto a absolutização do desvalor de ação (consubstanciado na mera desconformidade legal da conduta) e a consequente desconsideração do desvalor de resultado ao nível da imputação, bem como a diluição da ofensividade a bens jurídicos promovidas pelo Direito Penal de Precaução; quanto a lógica de responsabilidade coletiva e objetiva (em razão da mitigação e até da supressão das relações de causalidade altamente complexas) inerente aos delitos de acumulação, ignoram as pilastras básicas do que se conhece por Direito Penal: a responsabilidade individual (a imprescindibilidade do nexo causal) e subjetiva (a culpabilidade), bem como a ofensa a bem jurídico.

A tutela das gerações futuras só pode ser realizada através dos direitos e dos deveres das gerações presentes e aqui o Direito Penal Ambiental tem um papel relevante, mas nem exclusivo nem principal. Cabe ao Direito Penal a tutela de alguns bens jurídicos ambientais, dentro de um recortado espaço temporal, no interesse de pessoas determináveis, o que nos permitiu cravar a compatibilidade apenas do princípio jurídico-ambiental da equidade intrageracional com essa franja normativa.

Os recentes problemas ambientais possibilitaram a relembrança da responsabilidade diacrônica (voltada à proteção, à conservação e ao melhoramento das condições de existência das gerações presentes e futuras), mas, por outro lado, foi exigido de nós uma "preocupação" com os requisitos mínimos de imputabilidade e de responsabilidade jurídico-penais. A admissão de uma proteção direta das gerações futuras pelo Direito Ambiental implicou em assumir, de um lado, a face de Atlas na tutela do meio ambiente, tornando todos (ou quase todos) juridicamente responsáveis por meio dos mecanismos de imputação coletiva e de responsabilidade objetiva e solidária; e, por outro lado, a de Pilatos ao ignorar as bases jurídico-penais da imputação individual, da responsabilidade subjetiva e da necessidade de ofensa a bens jurídicos. Em síntese, o extremo "preocupar-se" com a proteção do meio ambiente deslocou o pêndulo dos pressupostos mínimos e inflexíveis de imputabilidade e de responsabilidade jurídico-penais para o "despreocupar-se" através da contaminação da seara jurídico-penal pelas ideias e teorias da jovem dogmática jurídico-ambiental. 


\title{
THE (DIACHRONIC) LIABILITY BY PROTECTION OF ENVIRONMENTAL GOODS: IMPORTANT NOTES FOR THE ENVIRONMENTAL CRIMINAL LAW
}

\begin{abstract}
We try to confront here the problem of (in)compatibility between the environmental and criminal legal rationalities concerning the protection of environmental goods in favor of the future generations, specially by difficulties of causality's verification in environmental damages in contexts of individual acts with accumulative consequences. The general objective of this paper is to outline the limits of Criminal Law in the protection of environmental goods in face of overestimated protection of the future generations. As justification, this literature review bases on dispensation's offense to legal goods, as well as on real dissolution of criminal liability's assumptions (mainly of individual' and subjective' nature of imputation, for example the indispensability of causality and guiltiness) presented namely in precaution's criminal law and accumulative crimes. The prevalence of the deductive method characterizes this methodological approach and the indirect documentation (marked by bibliographic research) consists in the research's technique used here. As a result, we conclued that the Environmental Criminal Law only has legitimacy to protect a few of the environmental's legal goods from the most serious offenses (according to the offense, ultima ratio, fragmentary and subsidiarity principles), inside of a determinated time space (in the interests of actual generations, the only determinable).
\end{abstract}

Keywords: Synchronic and diachronic liabilities. Symmetry and asymmetry obligations. Legal protection of the future generations.

\section{REFERENCIAS}

ALIER, Joan Martínez. De la economia ecológica al ecologismo popular. Barcelona: Icaria, 1995.

BALLESTEROS, Jesús. Ecopersonalismo y derecho al medio ambiente. In: HUMANA IURA: suplemento de derechos humanos da persona y derecho, Pamplona, Universidad de Navarra, vol. 6, 1996, pp. 15-36.

BAYERTZ, Kurt. Die Solidarität und die Schwierigkeiten ihrer Begründung. In: SEELMANN, Kurt (Hrsg.) Aktuelle Fragen der Rechtsphilosophie. Frankfurt am Main: Peter Lang, 2000, pp. 85-92.

BECCARIA, Cesare. Dos delitos e das penas. Tradução de José de Faria Costa. 4. ed. Lisboa: Publicações Fundação Calouste Gulbenkian, 2014.

BECK, Ulrich. La sociedad del riesgo: hacia una nueva modernidad. Traducción Daniel Jiménez, Jorge Navarro e Ma Rosa Borras. Barcelona: Paidós, 1998.

La sociedad del riesgo global. Traducción de Jesús Alborés Rey. Madrid: Siglo XXI, 2006.

BIM, Eduardo Fortunato. O mito da responsabilidade objetiva no Direito Ambiental Sancionador. Imprescindibilidade da culpa nas infrações ambientais. In: MILARÉ, Édis; MACHADO, Paulo Affonso Leme (Orgs.). Direito Ambiental: responsabilidade em matéria ambiental. São Paulo: RT, 2011, pp. 807-839.

BOBBIO, Norberto. A era dos Direitos. Tradução de Carlos Nelson Coutinho. Rio de Janeiro: Elsevier, 2004.

BOFF, Leonardo. Ethos Mundial: um consenso mínimo entre os humanos. Rio de Janeiro: Sextante: 2003. 
BOSSELMANN, Klaus. Direitos Humanos, ambiente e sustentabilidade. Revista do Centro de Estudos de Direito do Ordenamento, do Urbanismo e do Ambiente, Coimbra, Coimbra Editora, n. 21 , 2008, pp. 9-38.

BRONZE, Fernando José. Lições de introdução ao Direito. 2.a ed. Reimpressão. Coimbra: Wolters Kluwer Portugal/Coimbra Editora, 2010.

A responsabilidade, hoje (algumas considerações introdutórias). In: CORREIA, Fernando Alves; MACHADO, Jônatas E. M.; LOUREIRO, João Carlos (Orgs.). Estudos em homenagem ao Prof. Doutor José Joaquim Gomes Canotilho. Vol. I. Responsabilidade: entre Passado e Futuro. Coimbra: Coimbra Editora, 2012, pp. 183-208.

CAETANO, Matheus Almeida. Os delitos de acumulação no Direito Penal Ambiental. São Paulo: Editora Pillares, 2016.

CANOTILHO, José Joaquim Gomes. Justiça Constitucional e Justiça Penal. In: Revista Brasileira de Ciências Criminais, São Paulo, Editora RT/Instituto Brasileiro de Ciências Criminais, vol. 58, jan./fev. 2006, pp. 329-344.

CAPELLA, Vicente Bellver. El futuro del derecho al medio ambiente. In: HUMANA IURA: suplemento de derechos humanos da persona y derecho, Pamplona, Universidad de Navarra, vol. 6, 1996, pp. 37-61.

CAPRA, Fritjof. As conexões Ocultas: ciência para uma vida sustentável. Tradução de Marcelo Brandão Cipolla. São Paulo: Cultrix, 2005.

CASTANHEIRA NEVES, A. O problema da autonomia do direito no actual problema da juridicidade. In: RIBEIRO, J. A. Pinto (Coord.). O homem e o tempo. Liber Amicorum para Miguel Baptista Pereira. Porto: Fundação Eng. António de Almeida, 1999, pp. 87-114.

Digesta. Vol. 1. Reimpressão. Coimbra: Wolters Kluwer Portuga/Coimbra Editora, 2010a.

Digesta. Vol. 3. Reimpressão. Coimbra: Wolters Kluwer Portuga/Coimbra Editora, 2010b.

D’AVILA, Fabio Roberto. Ofensividade e crimes omissivos próprios (contributo à compreensão do crime como ofensa ao bem jurídico). Coimbra: Coimbra Editora, 2005.

Breves notas sobre o direito penal ambiental. In: Boletim do Instituto Brasileiro de Ciências Criminais, São Paulo, Instituto Brasileiro de Ciências Criminais, ano 18, n.o 214, set. 2010, pp. 15-16.

DOMINGUES, Victor Hugo. Acessoriedade administrativa e delitos ambientais. In: Revista de Crítica Jurídica, Curitiba, UniBrasil, vol. 2, set./dez. 2009, pp. 51-73.

FARIA COSTA, José de. O perigo em Direito Penal. Reimpressão. Coimbra: Coimbra Editora, 2000.

Uma ponte entre o Direito Penal e a Filosofia Penal: lugar de encontro sobre o sentido da pena. In: IDEM

(Org.). Linhas de direito penal e de filosofia: alguns cruzamentos reflexivos. Coimbra: Coimbra Editora, 2005, pp. 205-235.

Apontamentos para umas reflexões mínimas e tempestivas sobre o direito penal de hoje. In: Revista de Legislação e de Jurisprudência, Coimbra, Coimbra Editora, ano 139, n. ${ }^{\circ}$ 3958, 2009, pp. 48-55.

Ler Beccaria Hoje. In: BECCARIA, Cesare. Dos delitos e das penas. Tradução de José de Faria Costa. 4. ed. Lisboa: Publicações Fundação Calouste Gulbenkian, 2014, pp. 5-27.

FEIJOO SANCHEZ, Bernardo. Sobre a 'administrativização' do Direito penal na 'sociedade de risco'. Notas sobre a política criminal no início do século XXI. In: Revista Liberdades, São Paulo, Instituto Brasileiro de Ciências Criminais, vol. 7, mai./ago. 2011, pp. 23-62. 
FEINBERG, Joel. Harm to others. The moral limits of the criminal law. V. 1. New York: Oxford University Press, 1984.

FREELAND, Alejandro. ¿Permiso para contaminar; permiso para matar? Las autorizaciones administrativas y el delito ambiental. Cuadernos de doctrina y jurisprudencia penal, Buenos Aires, Ed. Ad - Hoc, vol. VII, n. ${ }^{\circ}$ 12, 2001, pp. 253-271.

FREUND, Georg. Strafrecht Allgemeiner Teil. Personale Straftatlehre. 2.Auflage. Berlin Heidelberg: SpringerVerlag, 2009.

FURTADO, Celso. O mito do desenvolvimento econômico. São Paulo: Círculo do Livro, s.d..

GARCIA, Maria da Glória F.P.D. O lugar do direito na protecção do ambiente. Coimbra: Almedina, 2007.

GARCIA-PABLOS DE MOLINA, Antonio. Introducción al Derecho Penal. Cuarta edición. Madrid: Editorial universitária Ramón Areces, 2006.

GETHMANM, Carl Friedrich. Langzeitverantwortung als ethisches Problem im Umweltstaat. Ihre Wahrnehmung in Staat und Gesellschaft (Zusammenfassung). In: KLOEPFER, Michael (Hrsg.). Umweltstaat als Zukunft. Juristische, ökonomische und philosophische Aspekte. Ergebnisse des Ladenburger Kollegs "Umweltstaat". Bonn: Economica Verlag, 1994, pp. 189-191.

GIDDENS, Anthony. As consequências da modernidade. Tradução de Raul Fiker. São Paulo: UNESP, 1991.

GOYOS JÚNIOR, Durval de Noronha. Dicionário jurídico Noronha: inglês-português, português-inglês. 6. ${ }^{a}$ ed. São Paulo: Observador Legal, 2006.

GRECO, Luís. A relação entre o direito penal e o direito administrativo no direito penal ambiental: uma introdução aos problemas da acessoriedade administrativa. In: Revista Brasileira de Ciências Criminais, São Paulo, Editora RT/Instituto Brasileiro de Ciências Criminais, vol. 58, jan./fev. 2006, pp. 152-194.

GUATARRI, Félix. As três ecologias. 5. a ed. Tradução de Maria Cristina F. Bittencourt. Campinas: Papirus, 1995.

GUIRAO, Rafael Alcacer. La Protección del Futuro y los Daños Cumulativos. In: Revista Electrónica de Ciencia Penal y Criminología Universidad de Granada, Granada, Universidad de Granada Editorial, n.o 04-08, 2002, pp. 130.

HEGEL, Georg Wilhem Friedrich. Princípios da Filosofia do Direito. Tradução de Orlando Vitorino. São Paulo: Martins Fontes, 1997.

HEISENBERG, Werner. Física e Filosofia. Tradução de Jorge Leal Ferreira. 2.a ed. Brasilia: Editora Universidade de Brasília, 1987.

HELLER, Agnes. Há obrigações sem direitos? Tradução de Vera Karam de Chueiri. In: Revista da Faculdade de Direito da Universidade Federal do Paraná, Curitiba, UFPR Editora, vol. 52, 2010, pp. 21-30.

KANT, Immanuel. Fundamentação da Metafísica dos Costumes. Tradução de Paulo Quintela. Lisboa: Edições 70,2007 . 
KERNOHAN, Andrew. Individual acts and accumulative consequences. In: Philosophical Studies, Netherlands, Kluwer Academic Publishers, vol. 97, Issue 3, feb. 2000, pp. 343-366.

KLOEPFER, Michael. A caminho do Estado Ambiental? A transformação do sistema político e económico da República Federal de Alemanha através da proteção ambiental especialmente desde a perspectiva da ciência jurídica. Tradução de Carlos Alberto Molinaro. In: SARLET, Ingo Wolfgang (Org.). Estado Socioambiental e Direitos Fundamentais. Porto Alegre: Livraria do Advogado Editora, 2010, pp. 39-72.

KUHLEN, Lothar. Der Handlungserfolg der strafbaren Gewässerverunreinigung ( $\$ 324$ StGB). In: Goltdammer`s Archiv für Strafrecht, Heildelberg, R. v. Decker's Verlag G. Schenck, 1986, pp. 389-408. Umweltstrafrecht - Auf der Suche nach einer neuen Dogmatik. In: Zeitschriftf für die gesamte Strafrechtswissenschaft, Berlin, De Gruyter, Band 105, Heft 4, 1993, pp. 697-726.

LESCH, Heiko Hartmut. Injusto y culpabilidad en derecho penal. Traducción de Ramón Ragués. Bogotá: Universidad Externado de Colômbia, 2001.

LORENZETTI, Ricardo Luis. Teoria Geral do Direito Ambiental. Tradução de Fábio Costa Morosini e Fernanda Nunes Barbosa. São Paulo: RT, 2010.

LOUREIRO, João Carlos. Autonomia do direito, futuro e responsabilidade integeracional: para uma teoria do Fernrecht e da Fernverfassung em diálogo com Castanheira Neves. In: Boletim da Faculdade de Direito da Universidade de Coimbra, Coimbra, Imprensa da Universidade de Coimbra, vol. 86, 2010, pp. 15-47.

MENDES, Paulo de Sousa. Vale a pena o direito penal do ambiente? Lisboa: AAFDL, 2000.

MENDOZA BUERGO, Blanca. El Derecho Penal en la sociedad del riesgo. Madrid: 2001.

El Derecho Penal ante la globalización: el papel del principio de precaución. In: BACIGALUPO, Silvina; CANCIO MELIÁ, Manuel (Orgs.). Derecho penal y política transnacional. Barcelona: Atelier libros jurídicos, 2005, pp. 319-342.

El delito ecológico $y$ sus técnicas de tipificación. Disponível em:<www.ecoiurislapagina.com/biblio/articulos/art125.htm>. Acesso em: 05. mai. 2010.

MÜLLER-TUCKFELD, Jens Christian. Ensayo para la abolición del derecho penal del medio ambiente.Traducción de Elena Íñigo Corroza y Ramon Ragués i Vallès. In: La insostenible situación del Derecho penal. Granada: Instituto de Ciencias Criminales de Frankfurt / Área de Derecho Penal de la Universidad Pompeu Fabra (Ed.), 2000, pp. 507-530.

NIETZSCHE, Friedrich. A genealogia da moral (uma polêmica). Tradução de Carlos José de Menezes. 10. ${ }^{a}$ ed. Lisboa: Guimarães Editores, 2008.

NUNES, António José Avelãs; COUTINHO, Jacinto Nelson de Miranda (Coords.). O direito e o futuro - o futuro do direito. Coimbra: Almedina, 2008.

ORTEGA Y GASSET, José. O que é Filosofia? Tradução de José Bento. Lisboa: Edições Cotovia / Biblioteca Editores Independentes, 2004.

OST, François. A natureza à margem da lei. A ecologia à prova do direito. Tradução de Joana Chaves. Lisboa: Instituto Piaget, 1995a. 
La responsabilité, fil d'Ariane du droit de l'environnement. In: Revue Internationale de Theorie du Droit et de Sociologie Juriduque: Droit et Socieété, Paris, L. G. D. J, vol. 30/31, 1995b, pp. 281-322.

Ecología y derechos del hombre. In: HUMANA IURA: suplemento de derechos humanos da persona y derecho, Pamplona, Universidad de Navarra, vol. 6, 1996, pp. 201-212.

O tempo do direito. Tradução de Maria Fernanda Oliveira. Lisboa: Instituto Piaget, 1999.

PRITTWITZ, Cornelius. Strafrecht und Risiko: Untersuchungen zur Krise von Strafrecht und Kriminalpolitik in der Risikogesellschaft. Frankfurt am Main: Vittorio Klostermann Verlag, 1993.

Sociedad del riesgo y Derecho penal. Traducción de Adán Nieto Martín y Eduardo Demetrio Crespo. In: DALBORA, José Luis Guzmán (Coord.). El penalista liberal. Controversias nacionales e internacionales en Derecho penal, procesal penal y Criminologia. Buenos Aires: Editorial Hammurabi, 2004, pp. 147-179.

Teoria pessoal do bem jurídico e as "Vítimas de Amanhã". Tradução de Raphael Boldt. Revista de Estudos Criminais, Porto Alegre, Instituto Transdisciplinar de Estudos Criminais, ano XV, vol. 61, 2016, pp. 9-24.

RICOEUR, Paul. Postface au Temps de la responsabilité. In: IDEM. Lectures 1 (1991). Paris: Éditions du Seuil, pp. 270-293.

Éthique et philosophie de la biologie chez Hans Jonas (1991). In: IDEM. Lectures 2 (1992). Paris: Éditions du Seuil, pp. 304-321.

RODRIGUES, Anabela Miranda. Direito Penal do Ambiente - uma aproximação ao novo direito português. In: Revista de Direito Ambiental, São Paulo, Editora RT/Instituto 'O direito por um planeta verde', vol. 2, 1996, pp. $14-24$.

RODRIGUEZ MOURULLO, Gonzalo. Limitaciones del Derecho Penal del medio ambiente: alternativa politico-criminales. In: DIAS, Jorge Eduardo de Figueiredo (Org.). A tutela jurídica do meio ambiente: presente e futuro. Coimbra: Coimbra Editora, 2005, pp. 159-177.

ROMEO CASABONA, Carlos Maria. Aportaciones del principio de precaución al Derecho Penal. In: IDEM (Ed). Principio de precaución, Biotecnología y Derecho. Bilbao: Comares, 2004, pp. 385-422.

RONZANI, Marco. Erfolg und individuelle Zurechnung im Umweltstrafrecht. Eine Studie zur Funktionalität der Strafrechtsdogmatik im Umweltschutz unter besonderer Berücksichtigung des Schweizer Rechts. Freiburg im Breisgau: Eigenverlag Max-Planck-Institut für ausländisches und internacionales Strafrecht, 1992.

ROXIN, Claus. Strafrecht. Allgemeiner Teil. Grundlangen. Der Aufbau der Verbrechenslehre. Band 1. 4. Auflage. München: Verlag C.H. Beck München, 2006.

¿Es la protection de bienes jurídicos una finalidad del derecho penal?. In: HEFENDEHL, Roland. (Ed.). La teoria del bien jurídico. ¿Fundamento de legitimación del Derecho penal o juego de abalorios dogmático? Madrid: Editorial Marcial Pons, 2007, pp. 443-458.

SAINT ÉXUPÉRY, Antoine de. O pequeno príncipe. Tradução de Vinna Maria Fonseca. Disponível em: <http://www.cirac.org/VMF-principe-pt.htm>. Acesso em: 19. 12.2013.

SAMPAIO, José Adércio Leite. Direito Fundamental ao meio ambiente saudável, adequado e ecologicamente equilibrado. In: SAMPAIO, José Adércio Leite; WOLD, Chris; NARDY, Afrânio (Orgs.). Princípios de direito ambiental: na dimensão internacional e comparada. Belo Horizonte: Del Rey, 2003, pp. 89-111.

SCHROEDER, Friedrich-Christian. Principio de precaución, Derecho Penal y riesgo. In: ROMEO 
CASABONA, Carlos Maria (Ed). Principio de precaución, Biotecnología y Derecho. Bilbao: Comares, 2004, pp. $423-433$.

SILVA DIAS, Augusto. "What if everybody did it ?": sobre a (in)capacidade de ressonância do Direito Penal à figura da acumulação. In: Revista Portuguesa de Ciência Criminal, Coimbra, Coimbra Editora, vol. 13, 2003, pp. 303-345.

Ramos emergentes do Direito Penal relacionados com a proteção do futuro (ambiente, consumo e genética humana). Coimbra: Coimbra Editora, 2008.

SOLA RECHE, Esteban. Principio de precaución y tipicidad penal. In: ROMEO CASABONA, Carlos Maria (Ed). Principio de precaución, Biotecnología y Derecho. Bilbao: Comares, 2004, pp. 475-491.

STEINDORF, Joachim. Umwelt-Strafrecht. 2, neubearbeitete und erweiterte Auflage. Berlin / New York: Walter de Gruyter, 1997.

STRATENWERTH, Günter. Zukunftssicherung mit den Mitteln des Strafrechts ? In: Zeitschrift für die gesamte Strafrechtswissenschaf, Berlin, De Gruyter, Band 105, Heft 4, 1993, pp. 679-696.

STUART MILL, John. On Liberty. London: Penguin Classics, 1985.

TAVARES, Juarez. Teoria do injusto penal. 2.a ed. Belo Horizonte: Del Rey, 2002.

TEUBNER, Gunther. A cúpula invisível: crise da causalidade e imputação coletiva. Tradução de Jürgen Volker Dittberner. In: TEUBNER, Gunther (Org.). Direito, Sistema e Policontextualidade. Piracicaba: Editora Unimep, 2005, pp. 190-232.

VIOLA, Eduardo. O movimento ecológico no Brasil (1974-1986): do ambientalismo à ecopolítica. In: PADUA, José Augusto. Ecologia Política no Brasil. Rio de Janeiro: Espaço e Tempo: IUPERJ, 1987, pp. 63-109.

VISSER'T HOOFT, H.Ph. Développement technologique et responsabilité envers les générations futures. In: Archives de Philosophie du Droit, Paris, Editions Sirey, Tome 36, 1991, pp. 31-47.

WALING, Cornélie. Das niederländische Umweltstrafrecht: eine Untersuchung zu den dogmatischen Grundlagen und zur praktischen Anwendung.Freiburg im Breisgau: Eigenverlag Max-Planck-Institut für ausländisches und internacionales Strafrecht, 1991.

WEISS, Edith Brown. In Fairness to Future Generations: International Law, Common Patrimony and Intergenerational Equity. New York: Transnational Publishers Inc. 1989.

Our rights and obligations to future generations for the environment. In: American Journal Of International Law, Cambridge, JSTOR, vol. 84, 1990, pp. 198-207.

WINTER, Gerd. Um fundamento e dois pilares: o conceito de desenvolvimento sustentável 20 anos após o Relatório Brundtland. In: MACHADO, Paulo Affonso Leme; KISHI, Sandra Akemi Shimada (Orgs.). Desenvolvimento sustentável, OGM e responsabilidade civil na União Européia. Tradução de Carol Manzoli Palma. Campinas: Millennium Editora, 2009, pp. 1-23.

WITTECK, Lars. Der Betreiber im Umweltstrafrecht. Zugleich ein Beitrag zur Lehre von den Pflichtdelikten. Baden-Baden: Nomos Verlagsgesellschaft, 2004. 
Trabalho enviado em 06 de fevereiro de 2017. Aceito em 30 de abril de 2017. 